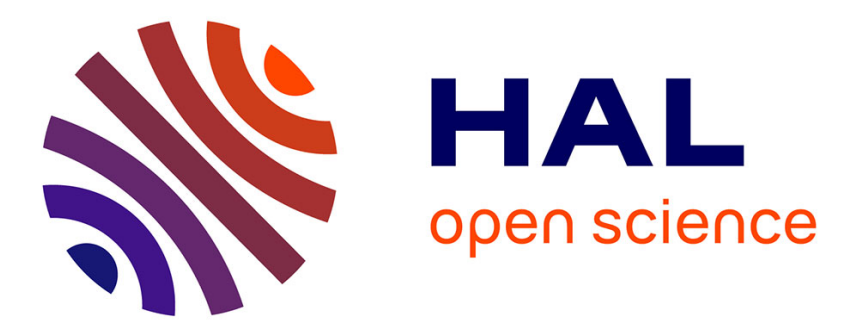

\title{
Managerial and Customer Costs of Price Adjustment: Direct Evidence from Industrial Markets
}

Mark J Zbaracki, Mark Ritson, Daniel Levy, Shantanu Dutta, Mark Bergen

\section{To cite this version:}

Mark J Zbaracki, Mark Ritson, Daniel Levy, Shantanu Dutta, Mark Bergen. Managerial and Customer Costs of Price Adjustment: Direct Evidence from Industrial Markets. Review of Economics and Statistics, 2004, 86 (2), pp.514-533. 10.1162/003465304323031085 . hal-02386836

\section{HAL Id: hal-02386836 https://hal.science/hal-02386836}

Submitted on 29 Nov 2019

HAL is a multi-disciplinary open access archive for the deposit and dissemination of scientific research documents, whether they are published or not. The documents may come from teaching and research institutions in France or abroad, or from public or private research centers.
L'archive ouverte pluridisciplinaire HAL, est destinée au dépôt et à la diffusion de documents scientifiques de niveau recherche, publiés ou non, émanant des établissements d'enseignement et de recherche français ou étrangers, des laboratoires publics ou privés. 


\title{
Managerial and Customer Costs of Price Adjustment: Direct Evidence from Industrial Markets*
}

\author{
Mark J. Zbaracki \\ University of Pennsylvania \\ Mark Ritson \\ London Business School \\ Daniel Levy** \\ Bar-Ilan University and Emory University \\ Shantanu Dutta \\ University of Southern California and London Business School \\ Mark Bergen \\ University of Minnesota
}

Last Revision: March 4, 2003

JEL Codes: E12, E31, L16, F31, F41

\begin{abstract}
* We are grateful to the management of the company we study for generous contribution of their time, for allowing us access their data, employees and customers, and for demonstrating remarkable open-mindedness by fully cooperating with us. We are particularly thankful to our primary contact at the company for her unflagging support throughout the project. Two anonymous referees and James Stock, the editor of this Review, gave us important comments and suggestions, which have greatly improved the paper. We are grateful to Andrew Caplin, the discussant at the American Economic Association meetings, to Julio Rotemberg, the discussant at the NBER Monetary Economics Research Program meeting, and to Larry Ball for insightful comments, conversations, and especially the encouragement. We also thank Bob Barsky, Susanto Basu, Alan Kackmeister, Bruce Kogurt, John Leahy, Greg Mankiw, Sourav Ray and Andy Young for comments and suggestions. Finally, we thank the seminar participants at Ben-Gurion University, Bar-Ilan University, University of Chicago, Emory University, University of Florida, Hebrew University at Rehovot, University of Minnesota, Ohio State University, University of Pennsylvania, University of Southern California, the January 1999 American Economic Association meetings in New York, NY, and the April 2000 NBER Monetary Economics Research Program meeting in Cambridge, MA, for comments and suggestions. We gratefully acknowledge financial support from the University of Chicago Graduate School of Business. All authors contributed equally: we rotate the order of authorship. The usual disclaimer applies.
\end{abstract}

** Address all correspondence to: Daniel Levy, Department of Economics, Bar-Ilan University, Ramat-Gan 52900, ISRAEL. Email: Levyda@mail.biu.ac.i1,Tel: 972-3-5318331, Fax: 972-3-5353180. 


\title{
Managerial and Customer Costs of Price Adjustment: Direct Evidence from Industrial Markets
}

\begin{abstract}
We study the price adjustment practices and provide quantitative measurement of the managerial and customer costs of price adjustment using data from a large U.S. industrial manufacturer and its customers. We find that price adjustment costs are a much more complex construct than the existing industrial organization or the macroeconomics literature recognizes. In addition to physical costs ("menu costs"), we identify and measure three types of managerial costs-information gathering, decisionmaking and communication costs, and two types of customer costs-communication, and negotiation costs. We find that the managerial costs are more than six times, and customer costs are more than twenty times, the menu costs. In total, the price adjustment costs comprise $1.22 \%$ of the company's revenue and $20.03 \%$ of the company's net margin. We show that many components of the managerial and customer costs are convex, while the menu costs are not. We also document the link between price adjustment costs and price rigidity. Finally, we provide evidence of managers' fear of "antagonizing" customers.
\end{abstract}


"I have no answer to the question of how to measure these menu change costs, but these [menu cost] theories will never be taken seriously until
an answer is provided."
Edward Prescott (1987, p. 113)
"Given the large number of theoretical papers that evaluate the implications of [price] adjustment costs, obtaining direct evidence that such costs
are present seems crucial."
Margaret Slade (1998, p. 104)

\section{Introduction}

One of the popular theories of price rigidity is the cost of price adjustment theory (Akerlof and Yellen, 1985; Mankiw, 1985). According to this theory, a seller must incur a fixed "menu cost" each time a price is changed and therefore, a seller is likely to make fewer price changes when such costs are present. As Blinder et al. (1998, p. 21) note, these costs have become “... one of the main strands of New Keynesian theorizing."

Numerous authors, however, have suggested that menu costs, if interpreted literally, may not be high enough to cause price rigidity. ${ }^{2}$ For example, according to McCallum (1986, p. 408), "it seems implausible that the actual resource costs of changing price tags are of significant magnitude." Consistent with this argument, Blinder et al. (1998) report survey findings that discourage a literal interpretation of menu costs.

Instead, some have argued that the truly substantial costs of price adjustment must be related to managerial time and effort ("thinking cost") and to customer considerations which form barriers to price changes. For example, Mankiw and Reis (2002) emphasize the conceptual importance of managerial decision costs for producing a more plausible Phillips Curve relation. In fact, Ball and Mankiw (1994, p. 142) “... suspect that the most important costs of price adjustment are the time and attention required of managers to gather the relevant information and to make and implement decisions." Similarly, Blinder et al. (1998, pp. 313-14) conclude that firms “... are loath to change prices because doing so would 'antagonize' their customers." They suggest that this issue [customers' antagonization] “... comes up so often that figuring out precisely what it means should be a high-priority item on any future research agenda." Rotemberg (2002) constructs a model in which a threat of consumers' angry reactions over unfair price increase can lead to price rigidity of the type often observed in the data.

The problem is that the actual magnitude of the managerial and customer costs of price adjustment is not known. The only study that reports empirical evidence on the practical significance of customer costs is the survey study of Blinder et al. (1998), who find that managers consider preserving customer relationships important. Hall et al. (1997) use the same methodology as Blinder et al., and report similar findings for the UK manufacturing firms. However, these studies do not report the quantitative magnitude of the managerial and customer costs of price adjustment.

\footnotetext{
${ }^{1}$ For theoretical studies of menu cost models see, for example, Mankiw (1985), Ball and Romer (1989, 1990), Blanchard and Kiyotaki (1987), Rotemberg (1982, 1987), Caplin and Spulber (1987), Caplin and Leahy (1991), Sheshinski and Weiss (1977), Slade (1998), and Danziger $(1999,2003)$, and the studies sited therein.

${ }^{2}$ These include Carlton (1986, 1989), Cecchetti (1986), McCallum (1986), Lindbeck (1987), Rotemberg (1987, 2002), Gordon (1990), Greenwald and Stiglitz, (1993), Ball and Mankiw (1994), Kashyap (1995), Carlton and Perloff (1996) and Meltzer (1995), among others.
} 
In this paper we seek to fill this gap by providing the first direct quantitative measurement of the managerial and customer costs of price adjustment. Because traditional sources of economic data are inappropriate for the task, we have developed a data-gathering research program, which involves an intensive analysis of the pricing practices of a one billion dollar industrial firm and its customers. ${ }^{\mathrm{B}} \mathrm{We}$ combine three data sources, (i) open-ended ethnographic interviews, (ii) non-participant observations, and (iii) company data along with industrial engineering time studies, to identify and measure individual components of price adjustment costs.

Many economists have emphasized the usefulness of the kind of data we have gathered. For example, Caplin (1993, p. 21) calls “... for more detailed empirical work and for increased understanding of the manner in which corporations actually arrive at pricing decisions." Blanchard (1994) believes that, when correctly done, we can learn a lot from listening to firms, and therefore, suggests going to the source of price change activity - the price managers - to gain insights about price adjustment. Likewise, authors such as Williamson (1985) and Durluaf (2001) have emphasized the importance of considering a wider range of data. For example, Durlauf (2001, p. 67) states that "the tendency of economists to treat statistical studies as automatically more informative than narrative studies has no justification in general and is clearly pernicious in contexts ... where the data are so poor.'

To briefly summarize our findings, we find that the managerial costs of price adjustment include costs of gathering information, costs of managerial decision on the price, and the cost of communicating the logic of the price changes to different members of the firm. The customer costs of changing prices include the cost of developing a communication strategy that can convey to customers in the best possible light the logic behind the price change decision, and the cost of negotiating with the customers who are not convinced about the new prices.

Quantitatively, we show that the managerial components of the price adjustment cost are substantial: the managerial costs are more than six times, and the customer costs of price adjustment are more than twenty times, the physical costs associated with changing prices. In dollar terms, the total annual cost of price adjustment in 1997 is $\$ 1,216,445$. Of this amount, $\$ 43,380$, or $3.57 \%$, is the cost of producing and distributing, the annual and the monthly updates of price sheets, and $\$ 280,150$, or $23.03 \%$, is the managerial cost which includes the cost of information gathering and analysis, systems cost, and the cost of the managerial time spent on the evaluation and decision of price changes. The remaining $\$ 892,915$, or $73.40 \%$, is the customer cost of price adjustment.

Further, we demonstrate that the managerial and customer components of the price adjustment cost are convex but the physical costs of changing prices_- "menu costs"—are not. We also discuss the link between the price adjustment costs and price rigidity by offering three examples of price rigidity. First, we

\footnotetext{
${ }^{3}$ The amount of time and effort needed to carry out such an in-depth study, have forced us to limit our study to one firm. Replicating a similar project at multiple companies, even if practically possible, would be prohibitively expensive.
} 
show that the firm changes its list prices annually even despite strong reasons and ample opportunities to change prices at other times during the year at, essentially, zero menu cost. Second, we show that when currency fluctuations required an increase in price in another country, the firm delayed its response due to increased customer negotiation and managerial costs. Finally, we provide evidence of manager's fear of "antagonizing" customers.

The paper is organized as follows. In section II, we describe the data. In section III, we describe the price change process, identify the price adjustment costs, and present their absolute size. In section IV, we present the relative size of price adjustment costs. In section $\mathrm{V}$, we show that the managerial and customer costs of price adjustment are convex. In section VI, we provide evidence on price rigidity. In section VII, we provide evidence on customer antagonization cost. In Section VIII, we discuss possible biases in our estimates and other measurement issues. Section IX concludes. In the Methodological Appendix we provide some details on the ethnographic interview methodology.

\section{Data}

Little is known about the managerial and customer costs of price adjustment. Standard data sources and methods of data collection are of no practical use in this case. The accounting systems firms use, for example, do not track the costs associated with changing prices. Such information is available only through careful analysis of the processes associated with changing prices. Therefore, we designed a research program to study these processes and determine the source and the magnitude of price adjustment costs. Our methods aimed at both eliciting a detailed description the process of changing prices and determining the costs associated with them.

To ensure the validity of our program, we have formed a cross-disciplinary research team. Two of us specialize in the use of ethnographic tools, another is trained in the time-and-motion methods of industrial engineering, and the remaining two study various aspects of pricing and price adjustment.

\section{A. Research Setting}

We study the pricing practices of a one billion dollar industrial firm that produces over 8,000 products used to help maintain machinery. The firm sells its products to other firms, either directly to the original equipment manufacturers of the machinery or to various distributors who sell them to the end users. We chose the site because we were promised full support from upper management and essential participants in the pricing process. 5 While the majority of the research was conducted at the organization's head office, we also spent a considerable amount of time at other locations that included many of the firm's customers around the US. The company made all participants, both within company

\footnotetext{
${ }^{4}$ See also Kashyap (1995), Lach and Tsiddon (1996), Dutta, et al. (1999, 2002), Genesove (1999), Levy, et al. (1998, 2002), Bergen, et al. (2003), Chen, et al. (2003), and Müller, et al. (2002).

${ }^{5}$ This was because several former students of one of the co-authors worked at this firm, and also because the upper management was interested in learning the magnitude of the company's price adjustment costs.
} 
and its customers, available to us. In addition, we received access to the company records. We presented our findings to the upper management and they concurred with them.

\section{B. Data Collection Methods}

We began by collecting three types of raw data. One type of data came from open-ended, taperecorded interviews with the individuals involved in the pricing process. These interviews followed standard ethnographic methods (Spradley, 1979), but were aimed very directly at determining what activities were required to change prices. The tape recordings from these interviews were then transcribed. A second type of data came from non-participant observation during a variety of pricing activities. Again, following standard ethnographic procedures, at least two members of the research team simply observed the activities of members of the firm. We sat in on meetings in which organizational members discussed list prices or special pricing arrangements (for example, international pricing), we observed pricing interactions among team members, and we observed the various tools used to determine prices. A third type of data came from internal documents generated by the organization in its pricing activities. They include price lists, minutes from past price change meetings, organization charts, pricing documents, emails, volumes of discounted pricing request forms, and other documents related to pricing. In total, we spent more than 720 man-hours in the field. The period of immersion produced over 500 pages of singlespaced interview transcripts as well as various documents and field notes we gathered.

To determine the magnitude of the price adjustment costs, we used time study methods of industrial engineering. Levy, et al $(1997,1998)$ and Dutta, et al (1999) have also used these methods to measure menu costs. However, unlike these studies, which focus only on the physical costs of changing prices, we are addressing all three types of costs: (i) physical, (ii) managerial, and (iii) customer costs of changing prices. As the literature on engineered work measurement indicates (Karger and Bayha, 1977), while industrial engineering time studies can be applied directly to repeated physical costs, these methods must be adapted to address the "knowledge workers" who are the primary contributors to the managerial and customer costs.

Consistent with time-and-motion methods, we began by developing a detailed description of the pricing process. The raw material from the ethnographic work provided a firm grounding for our measurements. From the detailed descriptions and the documents provided by the price change process managers and participants, we developed a detailed account of the steps involved in changing prices. We then developed a list of the participants engaged in each of these steps. From the list of participants, we proceeded to develop a detailed list of the activities required of these individuals for adjusting prices. We then measured the time involved in these activities, drawing either from their descriptions of the activities or from the company records. Where direct costs were available (for example, travel costs), we 
drew our measurements directly from them. Where direct costs were not available, we developed measures based on both the descriptions provided by the participants and observation of the tasks. When clarification was required, we returned to the site to get more details from the pricing coordinator. Finally, from these records and process charts, we produced a list of price change process participants, the time required, and the costs involved.

We shall note the differences between the method we use and the method adopted by Blinder, et al. (1998). Like Blinder et al., we go to managers for our data, but our methodology differs from theirs in several important ways. First, we went deep into one corporation to find insights on costs of adjustment, rather than going in less depth across a wide variety of companies as Blinder et al. did. Second, our ethnographic-observational data collection method is particularly useful for discovering new insights when little is known about a phenomenon. Interpretive research methods like ethnography follow a "discovery oriented" perspective (Wells, 1993) rather than a hypotheses testing approach as in the work of Blinder et al. Clearly such a discovery oriented perspective is particularly powerful when faced with a phenomenon, such as costs of price adjustment, whose structure, dimensions, and magnitude have yet to be completely understood, identified and measured. Third, we study the price change process and its various cost dimensions from the point of view of the process participants. In contrast, Blinder, et al's method adopts the theoretical viewpoint of the researcher. Fourth, the results Blinder et al. report, "fit neatly into economists' theoretical boxes" (Blinder, et al. 1998, p. 8). In contrast, we have to identify patterns, thematic groupings, recurring views and observations, etc., when we analyze the interview transcripts. The advantage of this approach is that it allows us to discover the essential dimensions of managerial and customer costs of price adjustment as perceived by the price change process participants themselves.

\section{Managerial, Customer, and Physical Costs of Price Adjustment: Absolute Measures}

"Pricing season around here lasts longer than the NFL." Pricing Analyst

The process for changing prices has two parts. The first part is the process of changing list prices. Changing the list price takes place over a period of several months, known as the "pricing season" to the firm employees. ${ }^{9}$ The second part of the price adjustment process includes developing a communications strategy to inform customers of the list price change, followed by negotiation with some customers. The

\footnotetext{
${ }^{6}$ Indeed, while our methods follow exactly the methods employed by any industrial engineer developing cost measures for a firm, our raw data in the transcribed interviews provide recorded detail generally not available to the industrial engineers who would perform such measurements internally.

${ }^{7}$ Our methodology is more similar to the methodology used by Bewley and Brainard (1993) and Bewley (1999) to study firm-level wage setting behavior.

${ }^{8}$ For more details on the ethnographic interview methodology, see the Methodology Appendix.

${ }^{9}$ We should note that the organizational members that participate in price change activities describe as "pricing" what economists call "price changes." Indeed, most of the pricing activity undertaken by this firm was price adjustment. Of the products we studied, only a small number of new products (about 50 out of 8,000) were added during the year. We should also note that we observed no change in the quality of the products during our study. The firm introduced a higher quality line of products during the period of this study, but we have not included the cost of setting prices for those products in cost of price adjustment measures we report.
} 
amount of time and resources spent on the negotiation, and the outcome of the negotiation depends on the customer and market situation. Occasionally additional negotiations will occur with specific customers later in the year depending on customer requests and competitors actions, but these negotiations are much less frequent.

The price change period, or the "pricing season," occurs once a year. The firm sets the start of the season based on the needs of the firm's customers. The largest customers need about 2-3 months of a lead-time before they publish new prices in January. The firm also requires about three months to set its prices, so the price adjustment period generally begins in late July or early August. The pricing season culminates with the distribution of new list prices, generally around November. These dates might vary depending on the complexity of the actual price changes.

The price adjustment period begins with the formation of a market strategy for the firm for that year. The market strategy varies from year to year. In a given year the strategy might address such goals as increasing profitability, increasing market share, stabilizing prices, maintaining or increasing the size of particular customers, or creating a specific image of the company (for example, as a low-cost producer or as a high quality producer). Once the market strategy is set, the firm must assess prices for all its 8,000 products, taking into account competitive information and the expected customer reaction. This complex process entails coordination and information gathering from various individuals from different parts of the firm.

\section{A. Managerial Costs of Changing Prices}

The managerial costs include information gathering costs, decision-making costs and internal communication costs.

\section{Information Gathering and Decision Making Costs}

Price change decision-making processes require a great deal of information gathering. The information gathered includes customer, company and competitor data. These information-gathering efforts involve many different organizational members. During the two years we studied, a pricing coordinator and pricing manager acted as the focal point for the data gathering efforts. For example, the pricing coordinator would seek competitor price sheets from the field sales representatives. The coordinator would also turn to the engineering group to determine the substitutability of the company's parts for comparable competitor parts. The coordinator might also turn to the marketing group for customer sales records and competitive information, to the finance group for sales records for specific parts, to the sales force for specific customer and competitor information, to the accounting group or to the production group for cost information, and to upper management for clarification of specific actions. From these various pieces of information, the coordinator builds a database that allows them to compare the competitors' prices with their prices. The information technology representative would help in the 
organization and storage of this information in a database form. This process occurs primarily during the first six months of the year-the time before the pricing season.

The cost of time spent by participants during this process is shown in Table 1a. These costs include all the time from January to July for all participants. These activities take up 10.75 man-months (which is the sum of the figures in the last column of Table 1a, from January to July) for a total cost of $\$ 94,600$ $(10.75$ months $\times 176$ hours/month $\times \$ 50.00$ per hour $=\$ 94,600)$. We include these information-gathering costs because they are required for the subsequent analysis of proposed price changes.

With the database in place, various individuals participate in a series of price change simulations and impact analyses in order to translate the pricing strategy into various specific pricing actions. The different participants' list and the time spent by them directly on the list price changes from August to December is provided in Table 1a. Again, the pricing coordinator and pricing manager serve as the focal point for these efforts. The pricing strategy will imply specific changes for various product lines in the company. Given the competitor, customer and company information, various organizational members, including people from marketing, sales, and finance will develop specific recommendations about which prices to increase, which prices to decrease, and which prices to leave unchanged. The pricing coordinator with the help of financial analysts will then take a first look at the specific proposed prices.

Our analysis of the price change decision process reveals a series of managerial activities of vast scope and complexity. Arriving at a list price for each of these 8,000 parts demands enormously complex analysis of the price structure of the firm, the pricing action of its competitors, and possible alternative pricing actions by the firm. In the words of the firm's one of the financial analysts:

\begin{abstract}
"We would do [analysis] at the overall business unit level and then I would pull down into these massive Excel spreadsheets: here is a customer and here are the 3,000 parts they bought last year and here is the 8,000 items in our price list; here are the proposed changes. What would be the impact of that on this customer? And then, let's say we did a [volume discount] program. They [the customer], of course would want their 10 highest volume parts [as part of the discount program] and we took ten percent off of that. What is the impact of that? ... So we had at least 8,000 lined spreadsheet doing these look up functions that would take two minutes to calculate."
\end{abstract}

The process described by the analyst is designed to assess the implication of the proposed price changes for a single customer, but will often be repeated for each major and some minor customers. Moreover, the coordinator and the analyst will often conduct multiple such analyses for major customers. Analyzing pricing actions is so complicated that the computing and accounting systems can constrain the price adjustment ability. For example, during the first year of our study, the complexity of the analysis process tied up the computer system for the organization, causing problems for other users of the computer system at the company. Such analysis even caused the entire company computer system to crash occasionally.

This analysis process may continue through several iterations until the various individuals involved come to some agreement about specific price recommendations. Then various participants, including 
marketing and sales managers review the proposed price changes. Finally, upper managers must review the new prices. They too may make changes. Such changes will demand yet another cycle of internal communication and analysis before the revised prices can go to the pricing analyst and publications group for distribution as the list prices.

The costs for these activities include all the personnel time spent in this process from August till December. These activities take up 17.8 man-months (which is the sum of the figures in the last column of Table 1a, from August to December) for a total cost of \$156,650 (17.8 months $\times 176$ hours/month $\times$ $\$ 50.00$ per hour $=\$ 156,650)$. The overall costs for information gathering and decision-making tasks from January till December amount to $\$ 251,250$ as given in Table 1a.

\section{Internal Communication Costs}

Once the list prices changes are determined, they must be communicated to the sales force. This requires group meetings with members of the pricing team, senior managers, territory managers and the field sales force. The sales force must understand and interpret both the meaning of the new prices and the significance of the price changes. Members of the sales force will usually comment on these changes, and may also speculate about the managers' motives for these changes. The internal communications costs, therefore, involve the time and the effort the pricing managers need to spend informing the sales force about the motives behind the price change. As we show below, the costs of poor internal communication can be quite significant.

We present the measures of the internal communication costs in Table 1b. According to the table, the cost of internal communication amounts to $\$ 28,900$. This consists of flying 17 area and territory managers to the company headquarters, where the pricing managers explain the new list prices. It also includes the time spent in meetings between the area managers and pricing coordinators or pricing managers at the corporate headquarters to discuss the new list prices and the time spent in getting their feedback. We find that the total managerial costs of changing prices at this company, as Table 1c indicates, was \$280,150 in 1997.

\section{B. Customer Costs of Changing Prices}

The customer costs of changing prices are incurred after the firm has determined its new price structure. The customer costs include the costs of presenting new prices to the customers and the costs of negotiating with some customers after the new list prices are presented.

\section{Customer Communication Costs}

After the new list prices are set the company must communicate them to its customers. The task parallels the internal tasks of communicating the pricing strategy to the salespeople, except that it now occurs for each customer. As a preparation for communicating the new prices to the distributors, the sales managers meet with territory managers to discuss their "communication strategy," which include 
evaluating the effect of the new prices on individual customers, creating presentation tools for presenting the new prices to the customers, and plan possible follow-up visits. For more severe price changes and more important customers, such as customers with purchase volume of half a million dollar or more, the salesperson's manager would attend these communication sessions as well. These meetings usually focus on the distributor's entire purchase history by product category and on examining how the price changes affect them.

The firm we studied divides its customer base into three categories: the largest 25 customers (Table $2 \mathrm{a}$ ), the middle 250 customers (Table $2 \mathrm{~b}$ ), and the remaining 1,100 customers (Table $2 \mathrm{c}$ ). All of the largest 25 customers, and a few of the next 250 customers receive a special attention. Consequently, the firm may send representatives from headquarters, the salesperson and the salesperson's manager to meet with these customers.

The next 250 customers, and a portion of the remaining 1,100 customers receive more limited attention. Generally the salesperson will meet with these customers alone and present the effects of the price changes. For select customers, the salesperson's manager will also accompany the salesperson. The bottom tier customers do not receive as much attention, and so they will usually complain to their salesperson. At a minimum, the salesperson may do some calculations to determine the effect on the customer. During the year of our study, these meetings and communications occurred during November and December of 1997 and ran into January and February of 1998. As Table 2d indicates, we find the cost of communicating the price changes to all customers totals $\$ 368,940$. By way of comparison, travel costs and fully allocated labor costs for the sales force and marketing during the same time period cost $\$ 757,135$. Thus, according to our measurements, approximately half the effort of the sales-force during this time was devoted to meeting with customers regarding the price changes.

\section{Customer Negotiation Costs}

Not all customers are convinced about the price change. Therefore, after the new list price is communicated to them, the firm enters into negotiation with them and tries to convince them of the logic of the price change. The bulk of these negotiations occur from November to February in concert with the annual list price changes made by the firm.

The negotiation costs include the time spent by territory managers and distributors in discussing bids with their major customers. These costs are smaller versions of the managerial costs associated with information gathering, decision making and communication (both internal and now external as well) costs of price adjustment. Not all customers require these kinds of negotiations. We find that two thirds of the top 25 customers and about 60 percent of the smaller customers (i.e., the middle 250 and the bottom 1,100 customers) require further negotiations (Tables $3 \mathrm{a}, 3 \mathrm{~b}, 3 \mathrm{c}$ ). While these negotiations mostly occur when there are price increases, not all of them lead to price reductions. Instead, the negotiation outcome can range anywhere from no price adjustment from the new list price to completely taking back any list price 
increases.

Negotiations can therefore act as a source of price rigidity for the firm, limiting its ability to change prices. When a negotiation reverses a list price increase, it creates complete rigidity because the price does not change from the previous year. In other instances, negotiations take back part of a price change, so the actual price does not change as much as the change in the list price. Whether these negotiations lead to price adjustments or not, the firm expends considerable resources evaluating the effects of the list price changes on a customer-by-customer basis.

Consider an example from one of the top 25 customers. During the pricing season we studied, a major customer called a senior vice-president to negotiate a new discount level. This request to negotiate generated an immense amount of work for the members of the organization. The senior vice-president and his staff flew to meet with the customer, which took two days. The team then returned to headquarters to gather additional data about the customer, similar customers, the firm's competitors, and the effect of the customer's purchases on the firm's revenue. The pricing team recalculated the effect of their price changes on that customer and similar customers. They met, suggested additional analysis, met again and decided on what they wanted to offer at the next round of meetings with the customer. Then they planned a presentation for this customer. The team then flew back with 3 corporate people, an area manager and the account manager for another two days.

This is not an unusual process for any negotiation with a customer holding a large account. New large accounts require even more effort. The reaction of a senior manager below captures the significant opportunity cost that customer negotiation costs impose:

\footnotetext{
"What struck me in the market is that we are doing pricing every time we turn around. It takes me a huge amount of time. I know that the area managers are struggling and spending a disproportionate amount of their time talking about pricing and I believe adding minimum value in doing that."
}

The manager found that pricing tended to crowd out other issues.

The middle and bottom tier customers require somewhat less negotiation effort. The middle category generally receives less attention from headquarters. In general, these negotiations involve the territory manager and, if necessary, the area manager. Again, the meetings would also require preparation and follow-up, though such effort would be less intensive. The smallest 1,100 customers receive even less personal attention. Often these negotiations are concluded over the phone, but the subsequent paperwork must go through the territory manager's manager, or some other manager at headquarters. Depending on the complexity of the request, such a small-scale negotiation can still take as long as half a day to a full day's work by someone at headquarters.

Any one of these individual price negotiations with a customer requires much less time and cost than is required to adjust the list prices. However, these individual negotiations must be tailored to each customer. Across all the 1,400 customers of the firm, these re-negotiation costs are therefore larger than the costs associated with changing list prices. These costs total $\$ 253,300$ for the top tier of customers 
(Table 3a), $\$ 172,500$ for the middle tier of customers (Table 3b), and $\$ 98,175$ for the bottom tier of the customers (Table 3c) yielding total negotiation costs of $\$ 523,975$ (Table 3d).

Thus, our measure of the total customer costs, as Table 3e indicates, amount to $\$ 892,915$. This cost includes the time spent in visits to customers to explain price changes, the time spent in associated analysis, and the time spent negotiating prices for individual customers. Finally, it includes the actual travel and other incidental costs incurred when visiting customers to discuss price changes. By way of comparison, the total labor and travel expenses for the sales force alone-not including the associated costs of members of headquarters who also participate in these discussions-come to about $\$ 2,500,000$. Thus, according to our measurements the customer costs of price changes comprise about a third of the sales force expenses.

\section{Physical ("Menu”) Costs of Changing Prices}

We conclude our analysis of the costs of adjusting prices by considering the physical costs of changing prices, the menu costs. According to Table 4, our measured total annual physical costs of changing prices are $\$ 43,380$. These costs include all steps required to publish new prices, and are most comparable to the costs of changing prices reported by Levy, et al. (1997 and 1998) in their study of supermarket chains, and Dutta, et al. (1999) in their study of chain drugstores. In our study the physical costs of price adjustment include the total cost of printing and distributing the annual list price sheets and the monthly supplemental list price sheets, as well as the costs of preparing and distributing electronic versions of these price sheets (see Table 4). The annual list price sheets' preparation requires approximately 80 hours of time by both managers and other employees to put in a form ready for printing. Internal records show a cost of $\$ 15,180$ to print the annual list price sheets. The preparation of the monthly supplemental list price sheets requires approximately 55 hours of time by managers and other employees to put the data into a form ready for printing, and an annual cost of approximately $\$ 10,000$ is spent on printing the supplemental price sheets.

\section{Total Costs of Changing Prices}

Combining all three components of the price adjustment costs, we find that the total cost of price adjustment the company incurred during 1997 was $\$ 1,216,445.00$. Of this cost, the physical (menu) cost comprise only $3.57 \%$, the managerial cost $-23.03 \%$, and the customer costs-73.40 percent. Thus,

almost three quarters of the total price adjustment costs are accounted for by customer costs, and slightly less than one quarter is accounted for by the managerial "thinking" cost. The menu cost component appears negligible in comparison to the other two components.

\section{Managerial, Customer, and Physical Costs of Changing Prices: Relative Measures}

To assess the relative magnitude of the cost of changing prices we compare them to the company's 
revenues, operating expenses, gross margins, and net margins. In addition, we present the cost of changing prices per product carried. These measures are reported in Table 5.

According to the table, the physical menu cost comprises only $0.04 \%$ of the company's revenue. In contrast, the managerial and customer costs comprise $0.28 \%$ and $0.91 \%$ of the revenues, respectively. In total, the price adjustment costs comprise $1.23 \%$ of the company's revenues, which seems substantial, especially if judged in the context of the existing models of price rigidity. For example, in the model of Blanchard and Kiyotaki (1987), a price adjustment cost of $0.08 \%$ of the revenues (which they consider "very small") is sufficient to prevent a price adjustment. In the model of Ball and Romer (1990), menu cost of $0.70 \%$ of revenues (which they consider "non-negligible") is necessary to prevent a price adjustment. The price adjustment costs we find here certainly exceed these minimums.

As a proportion of the operating expenses, the menu, managerial and customer costs comprise $0.20 \%$, $1.40 \%$, and $4.56 \%$, respectively, for the total of $6.16 \%$. As a proportion of the net margin, the menu, managerial and customer costs comprise $0.68 \%, 4.61 \%$, and $15.01 \%$, respectively, for the total of $20.30 \%$, which seems quite substantial. Per product carried, the costs of price adjustment amounts to $\$ 154.16$, which is almost 40 times higher than the \$4.23 figure Levy, et al. (1997) report for large US supermarket chains. The main reason for this difference is the large managerial and customer cost components we find here. In addition, the company only produces and sells 8,000 products in contrast to over 25,000 products sold by supermarkets.

Finally, we look at the price adjustment costs relative to the frequency of price changes. For this we need to calculate the number of price changes the firm undertakes each year. Although the company carries only about 8,000 products and it changes the list prices of almost all of them each year, the actual number of price changes it actually undertakes each year is many times higher because of the individually negotiated prices, discounts, and rebates. For example, many of the company's top customers buy as many as 3,000 different products. Big customers like these will usually re-negotiate the prices of many of the products they purchase. Therefore, the actual number of price changes undertaken is quite high, in the range of 10,000-54,000 each year.

In the last row of Table 5 we present the price change costs per price change. As the table indicates, the physical cost of changing a price ranges between $\$ 0.80-\$ 4.34$, the managerial costs range between \$5.19-\$28.05, and the customer costs, between \$16.53-\$89.29. Thus, the total cost of changing a price ranges between $\$ 22.52-\$ 121.64$. This indicates that the cost of changing a price in this company is an order of magnitude higher than in the retail supermarket or drugstore industry. We believe this is because our measures here explicitly incorporate the managerial and customer cost components of changing prices. In the supermarket and drugstore industry studies, in contrast, Levy, et al. (1997, 1998) and Dutta,

\footnotetext{
${ }^{10}$ For comparison purposes we note that according to Levy, et al. (1997, 1998), average supermarket each week changes 3,916 prices (Levy, et al., 1997, Table I, p. 797), which on annual basis (50 weeks) yields 195,800 price changes. Similar calculation using chain drugstore data reported by Dutta, et al. (1999, Table 1, p. 689) indicates that each year average chain drugstore changes 56,550 prices.
} 
et al. (1999), report that the physical cost of changing prices comprises the main component of the cost of price adjustment.

For comparison purposes we note three other studies that report quantitative measures of the costs of price adjustment. Slade (1998) estimates the cost of adjusting prices of Saltine crackers in a retail supermarket industry and reports that total costs of price adjustment (which includes fixed as well as variable costs) comprise about 4 percent of revenue. Similarly, Willis (1999) estimates the cost of price adjustment (which by construction includes all types of costs) using Cecchetti's (1986) magazine price data and finds that these costs comprise about 4 percent of revenues. 11 While these studies confirm that costs of adjusting prices are more than trivial, they both use econometric methods to estimate the cost of adjusting prices. In contrast, here we provide direct measures of these costs. More importantly, their cost estimates include fixed components of price adjustment costs. We have tried to exclude fixed costs from our measures. Levy and Young (2002), study nominal rigidity of the Nickel Coke, and conclude that price adjustment cost as a proportion of the revenue was an order of magnitude higher than the figures we report here.

\section{Convexity of Price Adjustment Costs}

"All of these costs depend on the size of the price change." Pricing Manager

An important aspect of cost of price adjustment is the relationship between the cost of changing price and the magnitude of the price change. The existing literature focuses primarily on two approaches to the costs of price adjustment. In one approach, the cost of adjusting prices is a fixed or lump sum cost that is incurred each time a price is changed and thus, is independent of the size of the price change. A second approach considers the cost of changing prices as a convex function of the size of the price adjustment: the larger the price change, the larger the cost of changing prices. These two approaches have markedly different implications for the type of price rigidity we might observe. The limited empirical evidence that exists on this issue seems to support the fixed cost model. For example, Blinder, et al. (1998) find a support for the fixed cost model in their survey responses. Levy, et al. $(1997,1998)$ and Dutta, et al. (1999) also suggest that there is little evidence of convexity in the physical costs of price adjustments.

Our data on the physical costs of price adjustment is consistent with this evidence. The physical costs of changing prices consist of such tasks as constructing new price lists, printing and distributing new list prices and the monthly supplemental price sheets, and notifying suppliers. These tasks are repeated each month, whether the price change is large or small. Thus, we see no evidence of convexity for these physical costs of price adjustment.

We find that many dimensions of managerial costs of changing prices, however, are convex. The

\footnotetext{
11 Willis (1999) however, fails to report the standard errors of his estimates, making his estimates difficult to interpret.

${ }^{12}$ Levy and Young (2002) report that the price of a $6 \mathrm{oz}$ Coca-Cola (in the bottle and from a fountain) was $5 \notin$ beginning in 1886 , when it was first introduced to public, until 1959. Thus, they document a nominal price rigidity that lasted over 70 years!
} 
managers themselves pointed this out to us when we presented our findings to the firm's upper management: they themselves noted that the costs we were reporting were clearly related to the size of the price changes. Our observation of the price change process confirms their claim. The larger the proposed price change, the more people are involved, the more supporting work is done, and the more time and attention is devoted to the price change decisions. For example, one sales manager described the basis of these escalating costs:

\begin{abstract}
"At that time I was a territory manager so I had no pricing authority. The only authority I had was to go to my boss and I would say, "OK, here is the problem I've got." He would say "Fill out a request and we will lower the price for that account." So that is how the pricing negotiations went. At that time I went up the chain to make any kind of adjustments I had to make ... My five guys have a certain level [of discount] they can go to without calling me. When they get to the certain point they have to get my approval ... Then I have a price level before I have to go to Y..."
\end{abstract}

The increased activity occurs for both managers and customers. The managerial costs of price adjustment increase with the size of price adjustment because the decision and internal communication costs are higher for larger price changes. First, the increased costs occur because more people are involved. For example, during the first pricing season we studied, the company made a substantial price adjustment, while during the second pricing season the price changes were relatively small. During the first pricing season, we found that the price setting team consisted of seven people from both corporate headquarters and the sales force who spent three days before the start of the pricing season debating the market strategy. In the second pricing season, in contrast, the managers readily agreed on that year's goal, so the market strategy was not a source of contention. That year only three people shaped the strategy.

Second, the increased costs occur because larger price changes lead to more internal discussions. During the first year, the marketing group was proposing a substantial reduction in list prices for one product line, with the hope that it would send a signal to customers that the firm was both a high-quality but also a low-cost producer for that product line. That proposal met with considerable resistance from the sales force. This led to significant increases in the information gathering and decision making stages of managerial costs. The resistance led to calls from participants who did not agree with this suggestion, for more information about effects on the customers. For instance, the sales force was concerned about the effects on key customers. Consequently, the pricing team needed to do additional analysis on those customers in order to see what the effects would be, which demanded more time of the pricing and financial analysts.

Third, the increased cost occurs because larger price changes lead to more attention and controversy, making the resulting price change process much less linear. For instance, quite frequently questions raised during the impact analysis will send the price-setting team back to reconsider the assumptions or even gather additional information.

Customer costs of price adjustment also increase with the size of price adjustment because larger price changes lead to both higher negotiation costs and higher communication costs. Larger price changes 
generate an increased amount of discussion. For example, when the firm negotiated especially low prices with one major customer, the action attracted the attention all the way to the various vice-presidents reporting to the CEO of the firm. Such discussions do not stop with the price changes; they often continue after the new price has been established. In the particular instance we saw that the marketing group continued to face questions about its strategy and the rationale from other personnel in other parts of the organization.

Finally, when the firm makes a major price change, the organization incurs increased customer negotiation costs because it must take a number of additional actions to handle its customers' complaints and concerns. In this instance, when other customers learned about the special deal offered to another customer, they would ask salespeople why they didn't get similar deals. Thus any time a pricing action went beyond the range anticipated by customers or violated the pricing patterns from prior periods or brought the firm out of line with competitors, the customers would complain and react. ${ }^{1.3}$ The pricing managers had to spend additional time to deal with these customer concerns.

The salespeople will react in one of the two following time-consuming ways. First, the salespeople might craft careful explanations. For example, in 1997, when the size of the price increase on some products was unusually large (and out of line with competitors), the sales people spent a considerable amount of time preparing presentations that would show the effects of the price changes on their major customers, especially those that incurred the greatest price increases. For large and complicated price changes, these analyses draw in the services of the financial analyst as well. Second, the explanations may not be enough. The sales force then may need to renegotiate prices.

Our findings thus suggest that managerial and customer costs of changing prices are convex. The evidence shows that changing a price "disrupts" any number of activities for people working in sales and marketing, and can also have effects on various higher-level managers as well as on customers. The evidence shows that the disruption varies with the size of the price adjustment.

\section{Price Adjustment Costs and Price Rigidity}

"We can’t change prices biannually, it is not the culture here." Pricing Manager

As discussed in section III, the firm changes its list prices only once a year, during the "pricing season," which ends with a publication of the new list prices. ${ }^{4}$ The firm follows the once-a-year price adjustment policy despite ample opportunities to change prices at other times during the year. For example, in addition to the annual price list, the firm also publishes monthly supplemental price list. The firm uses the monthly supplement to introduce new products or to correct errors. In publishing the

\footnotetext{
${ }^{13}$ Rotemberg's (2002) model makes predictions consistent with this kind of behavior. In his model consumers periodically reassess the fairness of their supplier's attitude, for example, after noticing a price increase, and react accordingly. See Stiglitz (1999) for a discussion of the risks involved in deviating from the "norm" when making price adjustments. The findings we report seem particularly consistent with Okun's (1981) customer market and implicit contract theory. See also Kahneman, et al (1986).
} 
monthly update, the firm already incurs the physical costs of publishing and distributing such a price sheet to all its customers - the sort of lump sum costs of price adjustment generally captured by menu costs. Yet, it never changes any prices when distributing these monthly updates. Thus, the firm each month has an opportunity to adjust its prices at zero marginal menu cost as the monthly supplemental price lists are printed and mailed anyway. The firm, nevertheless, never chose to do that. Given that it would clearly be rational for the firm to adjust prices, at the very least in response to major changes in cost or demand that occur throughout the year, the evidence clearly suggests that the managerial and customer costs of changing prices, rather than physical menu costs, are likely to be the key factors in preventing these mid-year price adjustments.

Managers at corporate headquarters also said that there were times when they did not raise the list price as high as they wanted to because of the costs of adjustment-either the costs of later negotiation and price change reversal through discounts offered by the sales force, or the costs of convincing the sale force of the importance of the price change. The convexity of these costs only exacerbated these problems. The firm often reacted to major changes in supply and demand conditions slowly and/or partially because of the convex nature of the costs they faced in convincing and communicating these changes to other members of the organization and their customers. Given the convex nature of the price adjustment costs, pricing managers often felt it was not worth the fight to make major changes, and would propose smaller changes to list prices.

Thus, negotiations act as sources of price rigidity for the firm, limiting its ability to change prices. When a negotiation reverses a list price increase, it creates complete rigidity because the price does not change from the previous year. In other instances, negotiations take back part of a price change, so the price does not change as much as the list price changed.

In addition to selling products in the United States, the firm sells products in a number of foreign countries. Many of those products are produced in other countries, but some are produced in the United States and sold in foreign countries. Over the course of our study, the firm saw the currency grow continually weaker in one country in which it sold a substantial number of its U.S.-produced products. Since it sold these products in the currency of the foreign country, it was beginning to lose profits on those sales. Despite these losses, the firm did nothing to adjust these prices for some time. When asked why they weren't changing prices, a pricing analyst stated that "it was too costly to open the doors to negotiation" with its foreign customers. The exchange rate of the US dollar increased by more than 11 percent, before the company's managers even considered any action. Thus, only after a sustained period of losses did managers begin to discuss possible actions. After considerable discussion, and additional loss of another 5 percent, the firm finally chose to impose a surcharge to adjust its international price for the currency fluctuations. Thus, the price rigidity is caused by the prohibitively high cost of price

\footnotetext{
${ }^{14}$ The negotiated price changes typically take place within two months of the new list price sheet publication. Thus, the price changes are not
} 
adjustment.

Arguably, indexing prices to the exchange rate could have reduced the costs of price adjustment in this situation. When we asked the financial analyst about changing to an indexed pricing rule, however, he indicated that it would be too costly for them to implement. It should be noted that introduction of an indexation rule into price adjustment process is not similar to a simple change in price. Introduction of an indexation mechanism is actually a change in the form of pricing and in the form of price adjustment rule/mechanism, and therefore, is likely to be more costly than changing prices within the existing form of pricing. This should not be surprising in light of the managerial and customer costs of price adjustment we identified for mere price changes. Thus, this evidence predicts even greater rigidity in changing forms of price adjustment rules: when indexation is not the standard pricing practice, it may be difficult to get firms to index prices because that would mean a change in the rules of the game.

Our evidence therefore suggests two levels of rigidity: one level of rigidity occurs in the process of changing list prices, and a second level of rigidity occurs in the process of implementing the list price changes at the customer level. The second level of rigidity results from an additional cost of aligning organizational actions between the various participants in the price adjustment process.

An important issue in the costs of adjustment literature is the relationship between the cost of price adjustment and the frequency of price changes. While we do not have time series data on the frequency of price changes and the corresponding costs, we can use the information we gathered at this firm to speculate on the shape of this function. Given the existing system of price change processes, the physical costs of price adjustment will likely vary directly with the frequency of price change because all the physical tasks needed to change prices must be repeated. That means that the physical costs would double if the frequency of price changes doubled.

The implications for the managerial steps are more complicated. Based on our observations, we know that the managerial tasks constrain the ability of the organization when prices need to change more frequently. A pricing expert with many years of experience at this company stated how costly they found the pricing season, and that they would not consider changing prices more often because of these costs. Over the course of our study, we encountered a retired pricing manager who worked at the company during the mid-70s. He explained that they found it difficult, given their existing price change system, to change prices more frequently during those inflationary years. Although there was some urgency to change prices more frequently, according to the manager, "There was also a period of some rapid inflation back in the Carter years where we would barely get a price sheet printed and you would have to start working on another one, every 6 months or so." Given the description from that manager and other

scattered throughout the year.

${ }^{15}$ The finding of rigidity of the product prices in terms of foreign currency units is related to the phenomenon known as "pricing-to-market" in the international economics literature. However, as Bergin and Feenstra (2001) note, the phenomenon is actually best described as "local currency pricing" as defined by Devereux (1997). As Lane (2001) points out in his recent survey of this literature, the key ingredient of the most recent model of open economy is the introduction of imperfect competition and nominal rigidities (in the goods market, in the labor market, or in both) by means of menu costs or staggered contracts. See Lane (2001) and the studies cited therein for more details. 
information we gathered, we can speculate that most of the managerial steps required for price change decisions - information gathering, decision making, and internal communication-need to be repeated if the price change process is undertaken twice a year instead of once a year. It is possible that some of the managerial steps can be reduced or eliminated, but doubling the frequency of price changes will most likely require repeating the entire managerial price change process and most steps involved. Given the constraints on managerial time, their existing system could not accommodate the frequency of change required in those inflationary times. Only with a major change in the price change process and the related organizational structures could they have changed prices more frequently. Thus, more frequent price changes would require fundamental changes in the processes of changing prices and their costs could more than double.

It is less clear how the customer costs of price adjustment would change in response to the increase in the frequency of price changes. Again, given our existing data we can speculate on possible effects. During inflationary times customers were expecting prices to increase. The same pricing manager who was involved in pricing during the mid 1970s noted that in inflationary times the firm used price changes simply to try to recover increased costs. He observed:

\footnotetext{
"The [cost] increases we experienced during that [inflationary] time were very much largely driven by cost and our average costs were going up and we were trying to recoup that. ... [During] high-inflation period you could get away with the high price increases. I think there was expectations in the market place; our customers are saying 'I am able to inflate my prices to the end user so I shouldn't be surprised when my vendor raises their prices ...' The distributors could pass on their prices a lot of easier than they can now."
}

Under these circumstances, the customer costs of price adjustment may not double: because customers expect price changes they will accept them more easily and thus fewer resources must be devoted to renegotiations.

On the other hand, if the costs are stable then doubling the frequency of price changes could result in substantial customer cost of price adjustment. As demonstrated above, changing prices, especially when changes are not clearly called for, invites customers to complain, to demand discounts and rebates, and to ask to re-negotiate. Whether these negotiations lead to price adjustments or not, the firm expends considerable resources evaluating the effects of the list price changes on a customer-by-customer basis. Doubling the frequency of price changes when costs are stable may, therefore, more than double the customer costs of price changes.

\section{Customer Antagonization Cost}

"We will take it in the pants' rather than pass it on down to our customers." Major Distributor

We also offer some evidence on what Blinder, et al. (1999) call, costs of "antagonizing customers." Though we are not able to offer hard dollar measures of these costs, we offer qualitative evidence of their nature.

When we visited the company's customers, they would often express frustration as they tried to make 
sense of the firm's price changes. One aspect of customer antagonism costs is that price changes-even price decreases - draw attention to prices and require that the sales force justify the changes. As one salesperson said, "every time you have one of those price changes you have to go in there and you are opening a Pandora's box."

Changes in prices harmed the customer perceptions of the firm's reputation, integrity, and reliability. For example, according to one of the salespersons of the company, the constant price changes during early 1990s, hurt the company's image. In his words,

"It is getting to be a running joke that every December and January I am coming in with some [price] change...
They will say things like: 'Where does that come from? ... The direction is not consistent... You change
discounts, ... dramatically, we don't know if you are committed to us or not.",

We also found examples demonstrating how customer relationship concerns led to price rigidity. For example, a pricing manager described a situation where the company had made a mistake and listed too low a price. When they tried to raise the price because of the glitch, they faced such pressure that they decided not to change the price until the next year. In general, the company and its customers were more likely to postpone a price increase if it threatened issues associated with customer loyalty and brand equity. One customer observed that often, if they received a price increase from their supplier (the firm), they would usually "... take it in the pants" rather than pass it on down to their customers. The reason in his words is that "We said we weren't going to raise prices that year and I believe that once you say that, you should stick with it." In fact, we discovered that price rigidity was perceived by the company's customers to be a sign of "customer orientation" and therefore a good thing. Similarly, many customers were more positively disposed to do business with companies who only changed their prices according to a predictable time schedule. Indeed, price rigidity was a source of pride within a company because it indicated that one's relationship with customers were more important than the 'bottom line.'

Another important component of customer antagonization cost is the risk of setting precedents. Consider, for example, the decision to cut prices. Organizational members were extremely sensitive to the dangers involved in cutting prices. One member of the sales force aptly described cutting prices as "feeding the animal." A decision to cut prices sets up a dangerous cycle: cutting prices in order to get business this period, leads to a response by a competitor with a still lower price. This lower price puts return pressure on the firm to lower its prices again. Pricing actions in one period therefore have repercussions in future periods.

We find that the customer antagonism cost can arise even when there is a decrease in the price. For example, one customer complained about a price decrease because their systems were not set up to pass on the lower prices without incurring significant price adjustment costs. Others complained that they would have to explain these price decreases to their end customers. In fact, both the sales force and customers would sometimes argue against a price decrease because it would make the costs of a price increase in later years more expensive because of the need to convince customers that prices should go 
up again. Thus any price change that does not make sense for the customer can cause customer antagonism. 16

\section{Potential Biases and Other Measurement Issues}

In performing our measurements we tried to be as conservative as possible by including in the figures we report the costs of only those activities that we could directly link to price change activities. For example, our measure of the information gathering cost does not include the cost of other data collection activities such as data gathering from customers about new orders or inventory levels, as they are not directly related to price change decisions. Similarly, our measures of customer communication costs do not include costs of other types of communication, like the cost of informing relevant personnel about new products or new market entry strategies, since these do not relate directly to price change decisions.

Despite our efforts, however, we suspect that our measures may still overestimate or underestimate the true price adjustment costs. The main reason for the possible upward bias in our measures is the strong complementarities present between pricing and other activities of the firm. For example, the trips of territory managers and the field sales force to the firm's headquarters (Table 1b), or the trips of company price managers to the field (Tables $2 \mathrm{a}-2 \mathrm{c}$ and Table $3 \mathrm{a}-3 \mathrm{c}$ ), are prompted by customers' dissatisfaction with the company's pricing. It is, however, hard to imagine that these meetings are always exclusively devoted to pricing. For instance, a discussion of increasing prices might lead to a discussion of adding new features to a product. Therefore, issues such as investment in customer relations and in the image and reputation of the company, attempts to obtain information from the customers concerning their desired changes in the characteristics of the products, etc., may all be included in the price adjustment costs we report. If such complementarities exist, we may have overstated the costs of adjustment.

On the other hand, these complementarities might also suggest that price adjustment decisions and processes are embedded in other processes and activities in the firm that we did not study. For instance, it is possible that a meeting of marketing team to discuss marketing-related issues may turn into a discussion on pricing. The cost estimates we present come from elapsed-time measures of various pricing activities. It is therefore equally likely that because of the complementarities we have also understated the costs of price adjustment. We have evidence consistent with this interpretation. According to the company's field sales force, almost every meeting between members of the sales force and a customer ultimately turns on price. In the words of a senior manager:

\footnotetext{
"What struck me in the market is that we are doing pricing every time we turn around. It takes me a huge amount of time. I know that the area managers are struggling and spending a disproportionate amount of their time talking about pricing and I believe adding minimum value in doing that."
}

The manager found that pricing tended to crowd out other issues. Either way, these complementarities

\footnotetext{
${ }^{16}$ Numerous themes of this type we identified during our study seem to be in line with Stiglitz's (1999) argument, that the informational imperfections and the uncertainties firms face when making price change decisions make any price change risky. See also Rotemberg (2002).
} 
suggest that pricing is deeply embedded in other processes and activities.

There are several other reasons that suggest that we may have underestimated the true price adjustment costs. First, in calculating the costs of changing prices, we focused on the opportunity cost associated with price adjustment. We, therefore, report only those managerial and customer costs, which seemed to directly affect the managers' or the customers' opportunity costs and that we could directly link to the price change process. To this end, we do not include a variety of costs the firm paid to improve its pricing processes. These costs, though significant, appear to be fixed costs rather than variable costs of price adjustment. For example, this company spent millions of dollars on computer hardware and software systems for use in price change analysis, 1,1 on training and education programs for their corporate staff, upper management and sales force, etc. We have also excluded variable costs, which we couldn't tie directly to price changes.

Second, there are numerous organizational members who are not part of the central pricing team who were also called into price change activities over the course of the pricing season, but we have not included them in our measures. Thus, we have only included the time spent by the central participants on changing prices-leaving out many other organizational members who these participants would have contacted during their work regarding various price change issues and/or who have been peripheral participants in the price change process.

Third, there was no practical way of measuring several components of the managerial and customer costs of price adjustment, the "soft costs." For example, we have provided a detailed analysis of customer antagonization costs, yet we could not include them in our numerical measures of price adjustment costs because of the difficulty of quantifying them.

Fourth, we have excluded the emotional cost of disputes over price changes. A pricing analyst described how at one of the early pricing strategy meetings, a representative from the marketing group and one of the members of the sales force "... were shouting back and forth, ..." and the argument became so heated that "I thought they were going to throw punches." While we tried to measure the time associated with such conversations and disputes, our measures likely understate the significance of these costs for at least two reasons. First, these tensions manifest themselves in time spent by individuals in the company complaining and lobbying in support of their position. We found numerous examples of emails, and hours spent in the hallway and on the phone discussing the positions of various individuals on pricing issues. Second, our costs cannot capture the effects emotions might have on decisions to change or not to change the prices. $\frac{18}{10}$

An important question that our approach raises is: how can we differentiate between "pricing" and

\footnotetext{
${ }^{17}$ The hardware and software include electronic systems for various cost and price analysis, information systems connecting the company's computer and database systems within the organization and to the customer companies' systems, portable hardware and software systems designed to help the field sales force in analyzing the company's price change decisions, software systems for analyzing and managing discount programs, refunds, etc. See Zbaracki, et al. (2001) for more details.
} 
"price adjustment?" We believe the answer depends on what is meant by pricing. If by pricing we mean the pricing of new products, then these costs are mostly separate and therefore, not a problem. The firm only introduces about 50 new products a year, and the process for setting their prices occur separately from the processes we describe here. Certainly the cost of adding a new product to the price list would be part of the "menu costs," but given that the firm produces 8,000 products a year, the marginal printing and distribution cost is likely to be negligible, because these price lists (annual as well as monthly updates) are distributed regardless.

If "pricing" is interpreted to mean "the overall decision on what price to set," then it is not clear how one can separate the two because any internal discussion of price adjustment will likely be accompanied by a discussion of the overall price setting strategy. If by "the overall decision on what price to set" we mean the "cost of being in the business," then we have tried to avoid this. Our measures include only the resources devoted to price change decisions for which we were certain that the time and other resources the company uses on price change assessment and decision have alternative uses. Thus, we focus only on the opportunity cost of changing prices.

Another important issue that we need to address is the treatment of the cost the company incurred in assessing price change proposals but in the end decided not to adopt them. Should the cost of considering a price change count as the cost of price change if at the end it is decided not to change the price? The answer to this interesting question is not clear and can certainly be debated. In our opinion, and the strategy we followed in this paper, is that when the company contemplates a price change, analyses it potential effects, and in the end decides not to implement it, that is part of the price adjustment cost. In other words, in our opinion, the cost of deciding not to adjust price is also a cost of price adjustment. As a practical matter, however, we had no way of measuring these "contemplation costs" separately. 19

The important question, therefore, is, how might this difficulty affect the cost of adjustment figures we report. The correct way of doing these calculations is to consistently treat the numerator and the denominator when calculating the cost per price change. In terms of the numerator, i.e., the total cost of price adjustment, these measures include all the time and resources spent on all price change analysis, discussions, and decisions, regardless of whether the prices were changed or not. In terms of the denominator, it depends. If we calculate price change per product, than we divide the total cost by 8,000 . Because the actual number of product price changes during the pricing season we studied was over 7,900 (according to our contact in the company, only less than 100 product prices were not changed during that season), the figures we report are not substantially biased. That is, there is no substantial difference

\footnotetext{
${ }^{18}$ We should also note that our customer costs of price adjustment do not include the costs incurred by the company's customers. The customer costs we are reporting are only those affecting the company itself.

${ }^{19}$ We have discovered two instances where the company considered an adjustment to the form of pricing it used. In one case the company considered an adoption of indexation rule in its international pricing division, but chose not to adopt it because the perceived cost of adjustment (the managerial and customer costs) were prohibitively high. In the second case, the company decided not to change the way the prices of bundled packages were adjusted, again because the perceived cost of the change was too high. However, we did not really have any way of separating the cost of these contemplated changes from the rest.
} 
between total cost of price adjustment per contemplated price change $(\$ 1,216,445.00 / 8,000=\$ 152.06)$ and per actual price change $(\$ 1,216,445.00 / 7,900=\$ 153.98)$. If we consider the cost of price adjustment per price change, when we include the individually negotiated prices, then the magnitude of the bias is less clear because of our inability to determine the proportion of the individually negotiated prices whose changes were contemplated but in the end, not implemented. The ratio, however, will not necessarily be biased upward because we know that some price changes that were eventually made were never contemplated. ${ }^{20}$ None of these, however, bias our measure of the total price adjustment cost figures, if one agrees with our argument that the cost of contemplating price changes should count as the cost of price adjustment.

\section{Conclusion}

Price adjustment costs and their nature are central for macroeconomics and industrial organization and therefore economists have extensively studied their implications. While conference discussions 21 and essays by prominent scholars 22 are full of speculations about the likely magnitude of these costs, there is very little hard evidence on their nature and size. In this paper we fill this gap in the literature by providing the first direct evidence on the actual nature and magnitude of the managerial and customer costs, which many consider to be the most important components of price adjustment costs.

The evidence suggests that these costs of adjustment are substantial. The managerial "thinking" costs are nearly an order of magnitude larger than the physical costs of changing prices. The customer costs are far more than an order of magnitude large than the physical costs of changing prices. These costs are therefore likely to be far more important than the traditional "menu costs" of adjustment. Moreover, these managerial and customer costs, along with the soft costs we found, clearly show that pricing activities consume a considerable portion of a firm's activities and attention. Our quantitative evidence, then, suggests that managers must choose to allocate resources to pricing activities and the "production function of firms uses inputs not just to produce outputs but also price lists and prices" (Rotemberg, 2000, Bergen, et al., 2002).

Beyond the evidence on the magnitude of the costs of price adjustment, we also provide detailed evidence on what contributes to those costs. Three important lessons follow from the analysis. First, we demonstrate that these costs lead to price rigidity. Second, the evidence suggests that the internal structure of the organization plays an important role in shaping the outcomes of pricing interventions.

\footnotetext{
${ }^{20}$ We are unable to calculate the cost of price adjustment per contemplated price change when we consider individually negotiated prices because we don't know the proportion of the individually negotiated prices that the company contemplated changing but decided in the end not to change.

${ }^{21}$ For example, a publicly open debate on the relative magnitude and the importance of menu cost versus managerial cost of price adjustment took place at the January 1999 American Economic Association Meeting in New York at a session on New Developments in Price Dynamics, between Stiglitz (1999) and his discussant, Alan Blinder.

${ }^{22}$ See, for example, Carlton (1986, 1989), McCallum (1986), Lindbeck (1987), Rotemberg (1987), Gordon (1990), Greenwald and Stiglitz, (1993), Ball and Mankiw (1994), Kashyap (1995), Carlton and Perloff (1996) and Meltzer (1995).
} 
Third, the evidence demonstrates that convincing others of the merits of a price change leads to convexity.

Many of the cost of price adjustment components and their complex nature we identify and document seem to be a characteristic of primarily a multi-product producer. They would either be non-existent or would, at most, be trivial in a setting of a single product producer. Unfortunately, the overwhelming majority of the current theoretical cost of adjustment literature, with the exception of Sheshinski and Weiss (1992) and Lach and Tsiddon (1996), typically considers a single product producer. The implication of our finding, therefore, is that it may be fruitful to explore predictions of theoretical models that incorporate traditional as well as these newer dimensions of cost of price adjustment in a multiproduct producer setting.

While our findings are specific to the firm we study, we anticipate that the themes will likely generalize to other large industrial manufacturers selling large number of products of products in business-to-business settings, and selling in markets with few competitors through a sales-force with a substantial price negotiation power. This pricing method characterizes a large number of industries such as health care products, chemicals, automotive, high technology, etc. We, therefore, expect that the nature of the managerial costs will generalize to large companies dealing with multiple markets, multiple products and multiple people within the organization. The nature of customer costs we find should also generalize to any business-to-business markets where prices are negotiated. These costs will be higher where salespeople (or any other separate function) participate in the negotiation process. Convexity should also generalize to industrial markets and large companies facing managerial and customer costs. Finally, price rigidity as an outgrowth of these costs should also generalize to other large industrial manufacturers. The specific settings may change, and therefore the specific details such as the length of the pricing cycle, the organization of the price adjustment process, and the actual magnitude of price adjustment cost and its various components will likely vary from firm to firm. But regardless of the setting, the central point from these themes will likely remain: at most such companies, pricing will likely to be a complex process involving a large number of people and substantial amount of resources.

Both our quantitative and qualitative evidence, point to the importance of understanding the relationship between the firm and its customers (Okun, 1981). When prices change one of the most important costs is "selling" the new price to the customer. Managers, anticipating the challenge of "selling" the new price, lobby for different actions, creating significant internal costs. Customers facing a price change demand costly meetings and discussions with the sales force. Concerns about customer antagonism therefore drive many pricing decisions. Moreover, it appears that the customer costs are the most important reason that managerial costs are as large as they are. Clearly the firm can avoid these costs if it chooses not to change prices. Our evidence therefore suggests that the relationship between the organization and its customers may be one of the most important issues in the costs of adjustment. In this 
study we provide a broad outline of these costs, but more studies are needed to better understand how customer interactions drive price changes. For example, detailed research on how customers react to different price changes - price increases versus price decreases_could provide important information on asymmetry of the cost of price adjustments. Similarly, in order to understand how costs of adjustment affect the frequency of price changes, we need to better understand how customers react to more frequent price changes. A recent study by Rotemberg (2002) is an important step towards that direction.

Another theme raised by our evidence addresses how to make sense of the fixed costs involved in pricing processes. Over the course of our study we uncovered numerous fixed costs that firms incurred to improve their pricing processes: investments in computer systems, training, and pricing expertise. We have excluded these from the costs reported here. Nevertheless, our evidence suggest that these decisions about pricing processes may have an important effect on many aspects of price adjustment, from lowering future costs of price adjustment to improving future effectiveness in changing prices. This suggests that future research should look into these aspects of the price adjustment processes (Zbaracki, et al., 2001).

We also find that the actual price adjustment processes are substantially more complex construct than the existing literature recognizes. This shortcoming is true not only to the macroeconomic literature, but also to the industrial organization. The primary reason for this complexity is the fact that the company has to assess and decide on the optimality of the prices of 8,000 different products. Another aspect of this complexity, however, is the fact that during its assessment of these prices it has to consider also the products' relative prices. This is especially true in light of the fact that many of the company's customers buy hundreds and sometimes even thousands of different products, and they will certainly be sensitive to the relative prices of the products they buy from the same company. Thus, the importance of relative prices is another dimension of the complexity of the price adjustment process the company faces. Another contributing factor is the fact that the company we study seems to act as a true price-setter as opposed to price-taker. The company chooses when and how to adjust prices, and negotiates these with its customers.

Further, the magnitudes of various price adjustment costs that we find suggest a ranking of their importance, which is not in line with the existing theoretical literature. For example, the overwhelming majority of studies that incorporate price adjustment costs, typically model these costs as a fixed (or "menu") cost. While some authors (see, for example, Sheshinski and Weiss, 1977 and 1992) have emphasized the conceptual difference between physical costs of price adjustment and managerial decision costs, usually no such distinction is made at the actual modeling level. Mankiw and Reis (2002) explicitly model these managerial decision costs of price adjustment and their effects on the Phillips curve relationships, and suggest that macroeconomists need to think more broadly about the frictions that impede price adjustment. Our work suggests that this is a promising research direction.

Finally, our evidence suggests some issues that fit less well in existing economic theories. Over the 
course of our studies, we found that pricing activities are deeply embedded in existing social structures. We conclude by suggesting that we need to better understand the interaction between these social structures and the process of adjusting prices. Changes in pricing and pricing processes are socially negotiated (Zbaracki and Bergen, 1998). For example, the customer reactions that we identified are embedded in existing patterns of relationships. These patterns of interactions shape understandings of both price and pricing practices. In order to change prices, managers must take into account the existing social structure and the way that it shapes how people think about both price level and the pricing processes. Many of the costs of adjustment occur because the understandings of the participants in the pricing process are so deeply anchored in the existing social structure. These social dimensions offer a promising direction for future research and may hold the key to more effective models of adjustment costs and processes. 


\section{References}

Akerlof, George A., and Janet L. Yellen (1985), "A Near-Rational Model of Business Cycle, with Wage and Price Inertia." Quarterly Journal of Economics 100, 823-838.

Ball, Laurence, and N. Gregory Mankiw (1994), “A Sticky-Price Manifesto.” Carnegie-Rochester Conference Series on Public Policy, 127-152.

Ball, Laurence, and David Romer (1989), "The Equilibrium and Optimal Timing of Price Changes," Review of Economic Studies 56, 179-198.

Ball, Laurence, and David Romer (1990), "Real Rigidities and Nonneutrality of Money," Review of Economic Studies 57, 183-203.

Bergen, Mark, M. Zbaracki, S. Dutta, D. Levy, and M. Ritson (2002), "Beyond the Cost of Price Adjustment: Investments in Pricing Capital," manuscript, presented at the 2002 NBER Summer Institute Conference on Financial Markets and the Economy.

Bergin, Paul R. and Robert Feenstra (2001), "Pricing to Market, Staggered Contracts, and Real Exchange Rate Persistence," Journal of International Economics 54 (2), August, 333-359.

Bewley, T. and W. Brainard (1993), “A Depressed Labor Market, As Explained by Participants,” Yale University, February, mimeo.

Bewley, Truman F. (1999), Why Wages Don't Fall During a Recession (Cambridge, MA: Harvard University Press).

Blanchard Olivier J. (1994), "On Sticky Prices: Academic Theories Meet the Real World: Comment, in Monetary Policy, edited by N. Gregory Mankiw, Studies in Business Cycles, Vol. 29, Chicago and London: The University of Chicago Press, 150-54.

Blanchard Olivier J., and Nobuhiro Kiyotaki (1987), "Monopolistic Competition and the Effects of Aggregate Demand," American Economic Review 77, 647-666.

Blinder, Alan S., E. R. D. Canetti, D. E. Lebow, and J. B. Rudd (1998), Asking About Prices: A New Approach to Understanding Price Stickiness (New York, NY: Russell Sage Foundation).

Caplin, Andrew (1993), "Individual Inertia and Aggregate Dynamics," in Optimal Pricing, Inflation, and the Cost of Price Adjustment, edited by E. Sheshinski and Y. Weiss, Cambridge, MA: The MIT Press, 19-45.

Caplin, Andrew S., and John Leahy (1991), "State Dependent Pricing and the Dynamics of Money and Output," Quarterly Journal of Economics 106, 683-708.

Caplin, Andrew S., and Daniel F. Spulber (1987), "Menu Costs and the Neutrality of Money," Quarterly Journal of Economics 102, 703-725.

Carlton, Dennis W. (1986), “The Rigidity of Prices,” American Economic Review 76, 637-58.

Carlton, Dennis W. (1989), "The Theory and the Facts of How Markets Clear: Is Industrial Organization Valuable for Understanding Macroeconomics?" in Handbook of Industrial Organization, Volume 1, edited by Richard Schmalensee and Robert D. Willig, pp. 909-946. Amsterdam: North Holland.

Carlton, Dennis W., and Jeffrey M. Perloff (1994), Modern Industrial Organization (New York, NY: Harper Collins).

Cecchetti, Stephen G. (1986), "The Frequency of Price Adjustment: A study of the newsstand prices of magazines," Journal of Econometrics, Volume 31, 255-274.

Cyert, Richard M. and James G. March (1963), A Behavioral Theory of the Firm (Englewood Cliffs, NJ: Prentice Hall). 
Danziger, Leif (1999), "A Dynamic Economy with Costly Price Adjustment," American Economic Review 89 (4), 878-901.

Danziger, Leif (2003), "Inflation, Costly Price and Quantity Adjustments, and Time Spent in the Keynesian Regime," Economics Letters, forthcoming.

Devereux, Michael B. (1997), "Real Exchange Rates and Macroeconomics: Evidence and Theory," Canadian Journal of Economics 30, 773-808.

Durlauf, Steven N. (2001), "Manifesto for a Growth Econometrics," Journal of Econometrics 100 (1), 65-69.

Dutta, S., M. Bergen, D. Levy, and R. Venable (1999), "Menu Costs, Posted Prices, and Multiproduct Retailers," Journal of Money, Credit, and Banking 31, No. 4, November, 683-703.

Eisenhardt, Kathleen M., (1989), "Building Theories from Case Study Research," Academy of Management Review 14, 532-550.

Genesove, David (1999), “The Nominal Rigidity of Apartment Rents,” Review of Economics and Statistics, forthcoming.

Gordon, Robert J. (1990), "What is New-Keynesian Economics?” Journal of Economic Literature 28, 1115-1171.

Greenwald, Bruce, and Joseph Stiglitz (1993), "New and Old Keynesians," Journal of Economic Perspectives 7 (Winter), 23-44.

Hall, Simon, M. Walsh, and A. Yates (1997), “How Do UK Companies Set Prices?” the Bank of England, Working Paper No. 67, July.

Kahneman, Daniel, J. Knetsch, and R. Thaler (1986), "Fairness as a Constraint on Profit: Seeking Entitlements in the Market," American Economic Review 76, 728-741

Karger, Delmar W., and Bayha, Franklin H. (1977), Engineered Work Measurement (New York: Industrial Press, Inc).

Kashyap, Anil K. (1995), "Sticky Prices: New Evidence from Retail Catalogues," Quarterly Journal of Economics 110, 245-274.

Lach, Saul, and Daniel Tsiddon (1996), "Staggering and Synchronization in Price-Setting: Evidence from Multiproduct Firms." American Economic Review 86, 1175-1196.

Lane, Philip R. (2001), “The New Open Economy Macroeconomics: A Survey,” Journal of International Economics 54 (2), August, 235-266.

Levy, Daniel, M. Bergen, S. Dutta, and R. Venable (1997), "The Magnitude of Menu Costs: Direct Evidence from Large U.S. Supermarket Chains." Quarterly Journal of Economics 112, August, 791825.

Levy, Daniel and Andrew Young (2002), "The Real Thing: Nominal Price Rigidity of the Nickel Coke, 1886-1959," manuscript.

Lindbeck, Assar (1987), "Discussion of Julio Rotemberg's 'The New Keynesian Microfoundations'," in NBER Macroeconomics Annual, p. 115.

Mankiw, N. Gregory (1985), "Small Menu Costs and Large Business Cycles: A Macroeconomic Model of Monopoly," Quarterly Journal of Economics 100, 529-539.

Mankiw, N. Gregory and Ricardo Reis (2001), "Sticky Information Versus Sticky Prices: A Proposal to Replace the New Keynesian Phillips Curve," NBER Working Paper No. 8290, May.

McCallum, Bennett T. (1986), "On Real and Sticky-Price Theories of the Business Cycle," Journal of 
Money, Credit, and Banking, Vol. 18, No.4, November, 397-414.

Meltzer, Allan H. (1995), "Information, Sticky Prices, and Macroeconomic Foundations," Federal Reserve Bank of St. Louis Review 77, 101-118.

Müller, Georg, M. Bergen, D. Levy, and S. Dutta (2002), "Holiday Price Rigidity and Cost of Price Adjustment," WP No. 3-2002 (March), Bar Ilan University and WP No. 2002-08 (April), Emory University, presented at the NBER-CRIW Conference, Cambridge, MA, July 30, 2001.

Okun, Arthur M. (1981), Prices and Quantities: A Macroeconomic Analysis (Washington, DC: The Brookings Institution).

Prescott, Edward C. (1987), “Comment [on Rotemberg, 1987],” NBER Macroeconomics Annual, 110_ 114.

Rotemberg, Julio J. (1982), "Sticky Prices in the United States." Journal of Political Economy 90, 11871211.

Rotemberg, Julio J. (1987), “The New Keynesian Microfoundations.” NBER Macroeconomics Annual, 69-104.

Rotemberg, Julio J. (2000), "Discussant's Comments [on this paper]," NBER Monetary Economics Research Program Meeting, Cambridge, MA, April 28, 2000.

Rotemberg, Julio J. (2002), "Customer Anger at Price Increases, Time Variation in the Frequency of Price changes and Monetary Policy," NBER Working Paper No. 9320.

Sheshinski, Eytan and Yoram Weiss (1977), "Inflation and Costs of Price Adjustment," Review of Economic Studies 44, 287-303.

Sheshinski, Eytan and Yoram Weiss (1992), "Staggered and Synchronized Price Policies Under Inflation: The Multi-product Monopoly Case," Review of Economic Studies 59, 331-359.

Slade, Margaret E. (1998), "Optimal Pricing with Costly Adjustment: Evidence from Retail-Grocery Prices," Review of Economic Studies 65, 87-107.

Spradley, James P. (1979), The Ethnographic Interview (New York, NY: Holt, Rinehart, and Winston).

Stiglitz, Joseph E. (1999), "Towards a General Theory of Wage and Price Rigidities and Economic Fluctuations," American Economic Review 89 (2), 75-80.

Wells, William D. (1993), Discovery Oriented Consumer Research, 19, March, 489-504.

Willis, Jonathan L. (1999), "Estimation of Adjustment Costs in a Model of State-Dependent Pricing," Ph.D. Dissertation: Boston University.

Zbaracki, Mark and M. Bergen (1998), "The Social (Re)construction of Price and Pricing: Organizational Perspectives," Working Paper. 


\section{Appendix: Ethnographic Interview Method}

Our research aimed at addressing the question: what are the managerial and customer costs of changing prices? We chose to answer the question by asking the people who set prices. As Blinder, et al. (1998) note in their remarkable work, in choosing to go directly to the people who set prices, one faces a series of tradeoffs. Our choices took us in different directions, however. Where Blinder, et al. chose to seek a broad cross-section of companies, we sought depth in one firm. In addition, whereas Blinder and colleagues tried to maintain a very structured interview protocol, we chose a more ethnographic approach. Finally, whereas Blinder, et al. sought to translate economists' language into managers' language, we sought to translate managerial language (and observation of managerial action) into data that we hope economists can use. Despite these differences, we share with Blinder, et al. the conviction that the "ability to replicate research findings is the essence of scientific inquiry" (p. 48). Should others wish to adopt our methods, here we give a more detailed explanation of our method

Our data come directly from those responsible for setting prices. Three problems drove our choice of methods. One problem driving our methods was that of getting accurate measures of the cost of changing prices; we wanted to obtain objective data on those costs. Since firms do not measure such costs, we could not rely on accounting data. Furthermore, estimates from CEOs or pricing managers seemed unlikely to provide accurate data. Instead, we had to reconstruct those costs. Given that these costs were likely distributed across a variety of organizational members and customers, we needed to contact a variety of people in the organization. Because getting the costs sometimes required us to observe the activities of organizational members, we needed to spend considerable time at the firm. These various requirements led us to go deep into one organization and made a replication across additional firms prohibitively expensive. The benefit of our approach is that it provides detailed descriptions of the process of changing prices (including the variety of elements that contribute to the costs of changing prices), which makes it possible for us to measure the cost of changing prices.

A second problem that we faced was moving from economic models of price stickiness-and especially the costs of changing prices - to a managerial context. The task of moving from theory to practice presents a researcher with three increasingly subtle problems in obtaining objective data. One is what Blinder, et al. (1998, p. 53) describe as the problem of whether "economists' technical theories of price stickiness [could] be translated into crisp, clear prose" that practitioners could understand. As Blinder, et al. show, this difficulty can be overcome. A second problem, however, is that even if we can effectively translate economists' language, when we begin with economic language, our study will focus on theoretical speculations on where costs of changing prices might lie. We risk missing many possible situations that might contribute to price adjustment costs because we have not asked the right questions. A third problem is even more subtle. Given that we are asking questions, even if we avoid using economists' language or theory, we may introduce "demand effects" in the questions we ask. Simply by 
asking about a possible cost of changing prices, we may induce in the organizational members the notion that such a cost is relevant to their work. Hence, we need to be very careful to balance letting the informant present the problem in their language and ideas without losing sight of our objective of finding out the costs of changing prices.

These problems are issues in ethnographic work of moving between languages and settings. Different languages create different categories for experience. Ideally, "ethnographic descriptions should flow from the concepts and meanings native to the scene rather than the concepts developed by the ethnographer" (Spradley, 1979, p. 24). Ethnographic work does not aim to test scientific hypotheses. Instead, it seeks to induce theory by drawing from native concepts. The ethnographer, therefore, needs to carefully craft questions that evoke those native concepts without, wherever possible, imposing the researcher's scientific framework. While these methods may seem to follow the sort of "free form" interviews that Blinder, et al. (1998) sought to avoid, in fact they do follow a general structure, aimed at guiding the "informant" towards their specific categories and concepts. Following the methods of the ethnographic interview, our interviews incorporated the following structure.

\title{
1. Statement of Explicit Purpose: We began each of our interviews with a statement of explicit
}

purpose. The following is the script for that statement:

\begin{abstract}
"Let us begin by explaining a bit about our research. We are doing research on how organizations go about pricing their products. It turns out there is a great deal of academic research on how firms price their products, but very little research uses explicit information about the actual process of pricing a product. In particular, we are interested in how much it costs a firm to change the prices of its products: the managerial time, the staff time, the sales time, the time to develop systems, the time to communicate the changes to the customers, etc. Although we know that pricing products is a very difficult process, we know very little about how much time that difficult process takes. Consequently, the information that you provide to us will be extremely helpful for our understanding of the pricing process. It will help us in our teaching and research. In addition, we will provide the data to you so that you will have information on the magnitude of pricing in your firm."
\end{abstract}

2. Ethnographic Explanation. We next explained the nature of the project, the desire to understand pricing in their terms, and our wish to tape the interviews. 44 The following is the script for our explanation of the project:

\begin{abstract}
"Given that we want to know about how firms do pricing, you can expect that we will ask a great number of questions about what you do when you deal with the price of your products. We understand that pricing can be an extremely sensitive subject. You should know that we are primarily interested in the process by which you change prices, especially how much that costs. First, that means that even though we do study pricing, you are the expert here. We want to know how you participate in the pricing. We want your thoughts on pricing, what makes it difficult, and how the process works. Second, that means that everything that we ask here is confidential. Although we will ask for data about your prices, we are not interested in the prices themselves. We will never reveal any of your prices to anyone else out of the research team. We will also not reveal your name or the name of the company, your customers, your suppliers, or any specific prices. If necessary, we will disguise data in order to protect your confidential information. We will be taping the interviews. This helps us get the most accurate information possible from the interview. It also makes it easier for us to listen in the interview. Again, we will not reveal your name to anyone outside the research
\end{abstract}

\footnotetext{
${ }^{23}$ Here we give only a brief overview of these methods. For more details, see Spradley (1979). Our approach draws heavily from his account.

${ }^{24}$ As we discussed in our methods section, all but one informant agreed to be taped.
} 
team. Your confidentiality will be protected throughout the research.”

3. Interview Explanation. We then gave an overview of the process. We explained how the interview would proceed. This portion was simply an explanation of the format that we present below. We have order the subsequent questions to explain their purpose. In our explanation of the interview, we did not include the categories we present here; rather, we simply presented the questions.

4. Ethnographic Interview. Ethnographic interview methods rely on three types of questions: descriptive questions, structural questions, and contrast questions. Although we present the questions in these categories, in the actual interview, structural and contrast questions tended to follow a different structure.

a) Descriptive questions help get the informant to explain the broad elements of the pricing process. Without the informant's description of their role in changing prices, we can only speculate on what tasks might contribute to the costs of changing prices. Hence, descriptive questions seek to gain an increasingly detailed picture of the pricing process from the perspective of the informant. Ethnographers have learned that more detailed questions encourage informants to give more detailed answers. While we have tried to include some examples of the sort of detail we might include, these are more abbreviated instances than many of the questions we asked. Some examples of the descriptive questions we used:

\section{Friendly questions:}

Can you give us a little bit of background about your work at [the firm] just so we can have some background on how you got to your present position?

How long have you been at the firm? In what capacity?

\section{Ethnographic questions:}

Take us through your typical day. In any given day, how might you be involved in pricing? What roles might you take or where might you be involved in changing prices? What main issues involving prices might have crossed your desk?

We'd like to get a sense of some of the pricing history at [the firm]. What are some of the major pricing issues that you have encountered since you arrived at [the firm]?

We'd like to know something about your company and your distributors share knowledge of pricing.

What do distributors know about pricing at [your firm]?

What do distributors think about how [your firm] does its pricing? Are their disagreements between [your headquarters] and the field?

How do distributors affect pricing at [your firm]?

How do you deal with conflicts between distributors?

b) Structural questions are questions that aim to get a sense of how the informants structure their understanding of the pricing process. Once we have identified the ways that people are involved in 
pricing, we can start to get an idea of some of the factors that would contribute to the cost of changing prices. For example, in our interview with the pricing analyst, we quickly discovered that making prices public was a very complex process. In order to get a sense of how the different participants dealt with that process, we asked questions like the following question:

We'd like to know how [your firm] gets its prices out to its customers. Can you take us through the steps you go through to change your prices and make the new prices public?

\section{Some follow-up questions:}

Who are all the people that are involved in the process?

You said that you held lots of meetings. What were those meetings?

Who participated in the pricing meetings?

What happened at those meetings?

Similarly, one of the central tasks in changing a price turned out to be the rebates. Many different actors needed to process a rebate, so we'd also ask a similar question to understand the rebate process:

Can you take us through the process that you need to go through to file a rebate?

\section{Possible follow-up questions:}

Who do you need to interact with?

Who else is involved in the process?

What other paperwork do you need to complete?

What happens if the rebate is rejected?

c) Contrast questions are questions that help the ethnographer know what an individual means by a particular term. For our purposes of understanding the costs of changing prices, these questions were less important than descriptive and structural questions. Sometimes, however, these questions helped us understand how reactions to different price changes might differ. For example, when one of the customers mentioned instances where changes in price wouldn't matter, we would ask questions such as the following:

You mentioned that in some instances a one percent price change wouldn't make any difference. Can you tell us when a one percent price change would or wouldn't make a difference? 
Table 1a. Managerial Costs of Changing Prices: Information Gathering and Decision Making Costs

Managerial Time Spent on Information Gathering and Decision Making: Fraction of Month Spent on Pricing

\begin{tabular}{|c|c|c|c|c|c|c|c|c|c|c|}
\hline Pricing Season & $\begin{array}{l}\text { Information } \\
\text { technology }\end{array}$ & $\begin{array}{c}\text { Pricing } \\
\text { coordinator }\end{array}$ & $\begin{array}{l}\text { Pricing } \\
\text { manager }\end{array}$ & $\begin{array}{c}\text { Financial } \\
\text { analyst }\end{array}$ & $\begin{array}{c}\text { Staff } \\
\text { assistant }\end{array}$ & $\begin{array}{c}\text { Marketing } \\
\text { manager }\end{array}$ & $\begin{array}{c}\text { Vice } \\
\text { President }\end{array}$ & $\begin{array}{c}\text { Territory } \\
\text { Managers }\end{array}$ & $\begin{array}{c}\text { Sales } \\
\text { manager }\end{array}$ & Total \\
\hline January & 1.0 & 0.1 & 0.05 & 0.1 & 0.1 & 0.05 & -- & -- & -- & 1.4 \\
\hline February & 1.0 & 0.1 & 0.05 & 0.1 & 0.1 & 0.05 & -- & -- & -- & 1.4 \\
\hline March & 1.0 & 0.1 & 0.05 & 0.1 & 0.1 & 0.05 & -- & -- & -- & 1.4 \\
\hline April & 1.0 & 0.1 & 0.05 & 0.1 & 0.1 & 0.05 & -- & -- & -- & 1.4 \\
\hline May & 1.0 & 0.1 & 0.05 & 0.1 & 0.1 & 0.05 & -- & -- & -- & 1.4 \\
\hline June & 1.0 & 0.2 & 0.1 & 0.1 & 0.1 & 0.05 & -- & -- & -- & 1.55 \\
\hline July & 1.0 & 0.4 & 0.2 & 0.2 & 0.2 & 0.1 & 0.1 & -- & -- & 2.2 \\
\hline August & 1.0 & 1.0 & 1.0 & 1.0 & 0.5 & 0.1 & 0.1 & 0.1 & 0.1 & 4.9 \\
\hline September & 1.0 & 1.0 & 0.8 & 0.5 & 0.4 & 0.15 & 0.05 & 0.05 & 0.05 & 4.0 \\
\hline October & 1.0 & 1.0 & 0.6 & 0.4 & 0.3 & 0.15 & 0.05 & 0.05 & 0.05 & 3.6 \\
\hline November & 1.0 & 0.8 & 0.4 & 0.3 & 0.2 & 0.05 & 0.05 & 0.05 & 0.05 & 2.9 \\
\hline December & 1.0 & 0.6 & 0.2 & 0.2 & 0.2 & 0.05 & 0.05 & 0.05 & 0.05 & 2.4 \\
\hline Total Months & 12 & 5.5 & 3.55 & 3.2 & 2.4 & 0.9 & 0.4 & 0.3 & 0.3 & 28.55 \\
\hline $\begin{array}{l}\text { Total Hours } \\
\text { (Months * } 176 \\
\text { Hours/Month) }\end{array}$ & 2,112 & 968 & 625 & 563 & 422 & 158 & 70 & 53 & 53 & 5,025 \\
\hline $\begin{array}{l}\text { Total Cost @ } \\
\$ 50 / \text { hour }\end{array}$ & $\$ 105,600$ & $\$ 48,400$ & $\$ 31,250$ & $\$ 28,150$ & $\$ 21,100$ & $\$ 7,950$ & $\$ 3,500$ & $\$ 2,650$ & $\$ 2,650$ & $\$ 251,250$ \\
\hline
\end{tabular}


Table 1b. Managerial Cost of Changing Prices: Internal Communication Cost

\begin{tabular}{|c|c|c|c|}
\hline Task & Measure & Cost* & Source \\
\hline Flights to HQ & $17 @ \$ 1,200$ per trip & $\$ 20,400$ & $\begin{array}{l}\text { Measure based on other } \\
\text { reported costs; approved } \\
\text { by management }\end{array}$ \\
\hline Meeting & $\begin{array}{l}1 \text { day per Area/Territory manager } \times 8 \\
\text { hours per day } \times 17 \text { Area/Territory } \\
\text { Managers }=136 \text { hours }\end{array}$ & $\$ 6,800$ & $\begin{array}{l}\text { Measure based on } \\
\text { interview data }\end{array}$ \\
\hline Feedback & $\begin{array}{l}2 \text { hours per Area or Territory manager } \times \\
17 \text { Area and territory managers }=34 \\
\text { hours }\end{array}$ & $\$ 1,700$ & $\begin{array}{l}\text { Measure based on } \\
\text { interview data }\end{array}$ \\
\hline Total & & $\$ 28,900$ & \\
\hline \multicolumn{4}{|c|}{$\begin{array}{l}\text { * Costs are based on average annual salary, fully loaded for benefits and expenses, at } \$ 100,000 \text { per year. Assuming 2,000 hours per year, the } \\
\text { annual employee cost translates to } \$ 50 / \text { per hour. }\end{array}$} \\
\hline \multicolumn{4}{|c|}{ Table 1c. Managerial Costs of Changing Prices: Total Cost } \\
\hline Task & & & Cost \\
\hline \multicolumn{2}{|c|}{ Information Gathering and Decision Making (from Table 1a) } & & $\$ 251,250$ \\
\hline \multicolumn{2}{|c|}{ Internal Communication (from Table 1b) } & & $\$ 28,900$ \\
\hline Total Cost & & & $\$ 280,150$ \\
\hline
\end{tabular}


Table 2a. Customer Costs of Changing Prices: Top 25 Customers Communication Costs

\begin{tabular}{|c|c|c|c|}
\hline Task & Participants & $\begin{array}{c}\text { Hours or } \\
\text { Per item cost }\end{array}$ & Total Cost* \\
\hline \multirow[t]{3}{*}{ Customer presentation } & Territory manager & 12 hours & $\$ 600$ \\
\hline & Area manager & 12 hours & $\$ 600$ \\
\hline & Pricing manager or marketing manager & 12 hours & $\$ 600$ \\
\hline Travel & 3 trips & $\$ 1,200$ & $\$ 3,600$ \\
\hline \multirow[t]{3}{*}{ Preparation for presentation } & Territory manager & 2 hours & $\$ 100$ \\
\hline & Area manager & 2 hours & $\$ 100$ \\
\hline & Financial analyst or pricing assistant & 1 hour & $\$ 50$ \\
\hline Total per customer & & & $\$ 5,650$ \\
\hline Total for top 25 customers & $\$ 5,650$ per customer $\times 25$ customers & & $\$ 141,250$ \\
\hline
\end{tabular}

Table 2b. Customer Costs of Changing Prices: Middle 250 Customers Communication Costs

\begin{tabular}{|c|c|c|c|}
\hline Task & Participants & $\begin{array}{c}\text { Hours or } \\
\text { Per item cost } \\
\end{array}$ & Total Cost $*$ \\
\hline Presentation & $\begin{array}{l}\text { Territory manager } \\
\text { Area manager (weighted average, based on } \\
1 \text { out of } 4 \text { customers) }\end{array}$ & $\begin{array}{l}4 \text { hours } \\
1 \text { hours }\end{array}$ & $\begin{array}{c}\$ 200 \\
\$ 50\end{array}$ \\
\hline Travel & $\begin{array}{l}\text { Territory manager } \\
\text { Area manager (weighted average, based on } \\
1 \text { out of } 4 \text { customers) }\end{array}$ & $\begin{array}{l}\$ 600 \\
\$ 150\end{array}$ & $\begin{array}{l}\$ 600 \\
\$ 150\end{array}$ \\
\hline Bid preparation & $\begin{array}{l}\text { Territory manager } \\
\text { Area manager (weighted average, based on } \\
1 \text { out of } 4 \text { customers) }\end{array}$ & $\begin{array}{l}2 \text { hours } \\
0.25 \text { hour }\end{array}$ & $\begin{array}{l}\$ 100 \\
\$ 12.5\end{array}$ \\
\hline Total per customer & & & $\$ 1,112.50$ \\
\hline $\begin{array}{l}\text { Total for middle } 250 \\
\text { customers }\end{array}$ & \multicolumn{2}{|c|}{$\begin{array}{l}70 \% \text { of customers at } \$ 1,112.5 \text { per customer } \times 250 \\
\text { customers }\end{array}$} & $\$ 194,690$ \\
\hline
\end{tabular}


Table 2c. Customer Costs of Changing Prices: Bottom 1,100 Customers Communication Costs

\begin{tabular}{|c|c|c|c|}
\hline Task & Participants & $\begin{array}{c}\text { Hours or } \\
\text { Per item cost }\end{array}$ & Total Cost* \\
\hline $\begin{array}{l}\text { Respond to customer } \\
\text { complaint (phone } \\
\text { conversation) }\end{array}$ & Territory manager & 1 hour & $\$ 50$ \\
\hline $\begin{array}{l}\text { Total for bottom } 1,100 \\
\text { customers }\end{array}$ & $60 \%$ of 1,100 customers at $\$ 50$ per customer & & $\$ 33,000$ \\
\hline
\end{tabular}

Table 2d. Customer Costs of Changing Prices: Total Communication Costs

$\begin{array}{ll}\text { Top } 25 \text { Customers (from Table 2a) } & \$ 141,250\end{array}$

Middle 250 Customers (from Table 2b) $\quad \$ 194,690$

$\begin{array}{lr}\text { Bottom 1,100 Customers (from Table 2c) } & \$ 33,000\end{array}$

Total Communication Costs for All Customers $\quad \$ 368,940$ 
Table 3a. Customer Cost of Changing Prices: Top 25 Customers Negotiation Costs

\begin{tabular}{|c|c|c|c|}
\hline Task & Participants & $\begin{array}{c}\text { Hours or } \\
\text { Per item cost }\end{array}$ & Total Cost* \\
\hline \multirow[t]{3}{*}{ Customer presentation } & Territory manager & 12 hours & $\$ 600$ \\
\hline & Area manager & 12 hours & $\$ 600$ \\
\hline & Pricing manager or marketing manager & 12 hours & $\$ 600$ \\
\hline Travel & 3 trips & $\$ 1,200$ & $\$ 3,600$ \\
\hline \multirow[t]{4}{*}{ Preparation for negotiations } & Territory manager & 8 hours & $\$ 400$ \\
\hline & Area manager & 8 hours & $\$ 400$ \\
\hline & Pricing manager or marketing manager & 12 hours & $\$ 600$ \\
\hline & Financial analyst & 8 hours & $\$ 400$ \\
\hline \multirow[t]{5}{*}{ Meeting for negotiations } & Territory manager & 16 hours & $\$ 800$ \\
\hline & Area manager & 16 hours & $\$ 800$ \\
\hline & Pricing manager or marketing manager & 16 hours & $\$ 800$ \\
\hline & Financial analyst & & \\
\hline & & 16 hours & $\$ 800$ \\
\hline Travel & 4 trips & $\$ 1,200$ & $\$ 4,800$ \\
\hline Total per customer & & & $\$ 15,200$ \\
\hline Total for top 25 customers & \multicolumn{2}{|c|}{$\begin{array}{l}\$ 15,200 \text { per customer } \times 2 / 3 \text { customers per year negotiating } \\
\times 25 \text { customers }\end{array}$} & $\$ 253,300$ \\
\hline
\end{tabular}

Table 3b. Customer Cost of Changing Prices: Middle 250 Customers Negotiation Costs

\begin{tabular}{llrr}
\hline Task & Participants & $\begin{array}{c}\text { Hours or } \\
\text { Per item cost }\end{array}$ & Total Cost* \\
\hline Negotiation & Territory manager & 4 hours & $\$ 200$ \\
Travel & Territory manager & $\$ 600$ & $\$ 600$ \\
Bid preparation & Territory manager & 2 hours & $\$ 100$ \\
Approval & Area manager & 2 hours & $\$ 100$ \\
Headquarters & Analyst time & 2 hours & $\$ 100$ \\
$\begin{array}{l}\text { Customer follow-up } \\
\text { Total per customer }\end{array}$ & Territory manager & 1 hour & $\$ 50$ \\
\hline $\begin{array}{l}\text { Total for middle } \mathbf{2 5 0} \\
\text { customers }\end{array}$ & $\begin{array}{l}\mathbf{\$ 1 , 1 5 0} \text { per customer } \times \mathbf{0 . 6 0} \text { customers } \\
\text { each year } \times \mathbf{2 5 0} \text { customers } \\
\text { * Costs are based on average annual salary, fully loaded for benefits and expenses, at } \$ 100,000 \text { per year. Assuming } 2,000 \text { hours per year, the }\end{array}$
\end{tabular}


Table 3c. Customer Cost of Changing Prices: Bottom 1,100 Customers Negotiation Costs

\begin{tabular}{|c|c|c|c|}
\hline Task & Participants & $\begin{array}{l}\text { Hours or } \\
\text { Per item cost } \\
\end{array}$ & Total Cost* \\
\hline Negotiation & Territory manager & 0.5 hours & $\$ 25$ \\
\hline Analysis and bid preparation & Territory manager & 1 hour & $\$ 50$ \\
\hline Approval & Area manager & 0.25 hours & $\$ 12.5$ \\
\hline Headquarters analysis & Pricing assistant & $\begin{array}{l}10 \% \text { at } 0.25 \text { hours } \\
80 \% \text { at } 1 \text { hour } \\
10 \% \text { at } 4 \text { hours } \\
\text { Weighted average: } 1.225 \text { hours }\end{array}$ & $\$ 61.25$ \\
\hline
\end{tabular}

Total per customer

$\$ 148.75$ customers

* Costs are based on average annual salary, fully loaded for benefits and expenses, at $\$ 100,000$ per year. Assuming 2,000 hours per year, the annual employee cost translates to $\$ 50 /$ per hour.

Table 3d. Customer Costs of Changing Prices: Total Negotiation Costs

\section{Customer Group}

Top 25 Customers (from Table 3a)

Middle 250 Customers (from Table 3b)

Bottom 1,100 Customers (from Table 3c)

Total Negotiation Costs for All Customers

\section{Total Cost}

$\$ 253,300$

$\$ 172,500$

$\$ 98,175$

$\$ 523,975$ 
Table 3e. Total Customer Costs of Changing Prices

Task

Total Cost

Total Communication Cost (from Table 2d)

$\$ 368,940$

Total Negotiation Cost (from Table 3d)

$\$ 523,975$

Total Customer Costs

$\$ 892,915$ 
Table 4. Physical Costs of Changing Prices (Menu Costs)

\begin{tabular}{|c|c|c|c|}
\hline Item & Measured Hours & Cost* & Source \\
\hline \multicolumn{4}{|l|}{ Price list: } \\
\hline $\begin{array}{l}\text { Marketing } \\
\text { communication }\end{array}$ & $\begin{array}{l}80 \text { hours } \\
\text { (From time sheets and marketing } \\
\text { communication measures) }\end{array}$ & $\$ 4,000$ & $\begin{array}{l}\text { Self report (meets internal } \\
\text { accounting standards) }\end{array}$ \\
\hline Printing cost & N/A & $\$ 15,180$ & Data from bid sheets \\
\hline $\begin{array}{l}\text { Distribution cost: } \\
\text { Time } \\
\text { Postage }\end{array}$ & 8 hours & $\begin{array}{c}\$ 400 \\
\$ 2,200\end{array}$ & \\
\hline $\begin{array}{l}\text { Create customer specific } \\
\text { price lists }\end{array}$ & 7 hours & $\$ 350$ & $\begin{array}{l}\text { Measure based on pricing } \\
\text { analyst report }\end{array}$ \\
\hline \multicolumn{4}{|l|}{$\begin{array}{l}\text { Supplemental price lists } \\
\text { (monthly): }\end{array}$} \\
\hline $\begin{array}{l}\text { Marketing } \\
\text { communication }\end{array}$ & 55 hours & $\$ 2,750$ & $\begin{array}{l}\text { Measure based on annual } \\
\text { costs; }\end{array}$ \\
\hline Printing & - & $\$ 10,000$ & $\begin{array}{l}\text { Measure based on annual } \\
\text { costs }\end{array}$ \\
\hline Mailing & - & $\$ 4,000$ & \\
\hline $\begin{array}{l}\text { Create master file, cut } \\
\text { prices, format disks } \\
\text { and EDI }\end{array}$ & 90 hours & $\$ 4,500$ & $\begin{array}{l}\text { Measure based on pricing } \\
\text { analyst reports }\end{array}$ \\
\hline
\end{tabular}

Total

* Costs are based on average annual salary, fully loaded for benefits and expenses, at \$100,000 per year. Assuming 2,000 hours per year, the annual employee cost translates to $\$ 50 /$ per hour. 
Table 5. Absolute and Relative Measures of Costs of Changing Prices (in \% or in 1997 \$s)

\begin{tabular}{|c|c|c|c|c|}
\hline & $\begin{array}{l}\text { Physical Cost } \\
\text { (Menu Cost) }\end{array}$ & $\begin{array}{c}\text { Managerial } \\
\text { Cost }\end{array}$ & $\begin{array}{c}\text { Customer } \\
\text { Cost }\end{array}$ & Total Cost \\
\hline Annual Cost $(\$)$ & $\$ 43,380$ & $\$ 280,150$ & $\$ 892,915$ & $\$ 1,216,445$ \\
\hline $\begin{array}{l}\text { Annual Cost as a Percentage of } \\
\text { Total Cost }(\%)\end{array}$ & 3.57 & 23.03 & 73.40 & 100 \\
\hline Cost/Revenues (\%) & 0.04 & 0.28 & 0.89 & 1.22 \\
\hline Cost/Operating Expenses (\%) & 0.22 & 1.39 & 4.44 & 6.05 \\
\hline Cost/Gross Margin (\%) & 0.14 & 0.93 & 2.97 & 4.05 \\
\hline Cost/Net Margin (\%) & 0.71 & 4.61 & 14.70 & 20.03 \\
\hline Cost per Product Carried (\$) & $\$ 5.42$ & $\$ 35.02$ & $\$ 111.61$ & $\$ 152.06$ \\
\hline Cost per Price Change $(\$)$ & $\$ 0.80-\$ 4.34$ & $\$ 5.19-\$ 28.05$ & $\$ 16.53-\$ 89.29$ & $\$ 22.52-\$ 121.64$ \\
\hline \multicolumn{5}{|c|}{$\begin{array}{l}\text { Notes: } \\
\text { 1. The source of the annual cost figures in the first row, are Table } 4 \text { (physical cost), Table 1c (managerial cost), and Table } 3 \mathrm{e} \text { (customer } \\
\text { cost). } \\
\text { 2. The particular division of the company we study constitutes } 12 \% \text { of the company's total annual revenues. We have therefore adjusted } \\
\text { accordingly the denominator of all four ratios reported in rows } 2-5 \text {. } \\
\text { 3. The figures on the company's annual revenues, operating expenses, gross margin, and net margin, were taken from the company's } \\
1997 \text { Financial Report included in the Consolidated Balance Sheets submitted to the company's shareholders and its Board of } \\
\text { Directors. } \\
\text { 4. At the request of the company's management, the figures reported in the table have been rounded so that it is impossible to determine } \\
\text { the company's exact revenues, operating expenses, gross margin, and net margin. This is designed to ensure that the company } \\
\text { remains anonymous. If we were to present the exact figures, which would make it possible to determine the company's revenues, } \\
\text { operating expenses, gross margin, net margin, etc., then one could perhaps locate and determine the company's identity by a simple } \\
\text { search on the internet because the company annually submits its financial reports to its stockholders and its board. } \\
\text { 5. Cost per product carried is calculated by dividing the total annual cost by } 8,000 \text {. } \\
\text { 6. Cost per price change is calculated by dividing the total annual cost by the total number of price changes during the year. The latter } \\
\text { figure ranges from about } 10,000 \text { to about } 54,000 \text { price changes each year, depending on the number of actual transactions involving } \\
\text { individually negotiated prices. }\end{array}$} \\
\hline
\end{tabular}

